\title{
Influence of modelled soil biogenic NO emissions on related trace gases and the atmospheric oxidizing efficiency
}

\author{
J. Steinkamp ${ }^{1}$, L. N. Ganzeveld ${ }^{2}$, W. Wilcke ${ }^{3}$, and M. G. Lawrence ${ }^{1}$ \\ ${ }^{1}$ Department of Atmospheric Chemistry, Max-Planck-Institute for Chemistry, Mainz, Germany \\ ${ }^{2}$ Department of Environmental Sciences, Chairgroup Earth System Sciences, Wageningen University and Research Centre, \\ Wageningen, The Netherlands \\ ${ }^{3}$ Geographic Institute, Johannes Gutenberg University, Mainz, Germany
}

Received: 22 April 2008 - Published in Atmos. Chem. Phys. Discuss.: 30 May 2008

Revised: 12 February 2009 - Accepted: 13 April 2009 - Published: 23 April 2009

\begin{abstract}
The emission of nitric oxide (NO) by soils (SNOx) is an important source of oxides of nitrogen $\left(\mathrm{NO}_{\mathrm{x}}=\mathrm{NO}+\mathrm{NO}_{2}\right)$ in the troposphere, with estimates ranging from 4 to $21 \mathrm{Tg}$ of nitrogen per year. Previous studies have examined the influence of SNOx on ozone $\left(\mathrm{O}_{3}\right)$ chemistry. We employ the ECHAM5/MESSy atmospheric chemistry model (EMAC) to go further in the reaction chain and investigate the influence of SNOx on lower tropospheric $\mathrm{NO}_{\mathrm{x}}, \mathrm{O}_{3}$, peroxyacetyl nitrate $(\mathrm{PAN})$, nitric acid $\left(\mathrm{HNO}_{3}\right)$, the hydroxyl radical $(\mathrm{OH})$ and the lifetime of methane $\left(\tau_{\mathrm{CH}_{4}}\right)$. We show that SNOx is responsible for a significant contribution to the $\mathrm{NO}_{\mathrm{x}}$ mixing ratio in many regions, especially in the tropics. Furthermore, the concentration of $\mathrm{OH}$ is substantially increased due to SNOx, resulting in an enhanced oxidizing efficiency of the global troposphere, reflected in a $\sim 10 \%$ decrease in $\tau_{\mathrm{CH}_{4}}$ due to soil $\mathrm{NO}$ emissions. On the other hand, in some regions SNOx has a negative feedback on the lifetime of $\mathrm{NO}_{x}$ through $\mathrm{O}_{3}$ and $\mathrm{OH}$, which results in regional increases in the mixing ratio of $\mathrm{NO}_{\mathrm{x}}$ despite lower total emissions in a simulation without SNOx. In a sensitivity simulation in which we reduce the other surface $\mathrm{NO}_{\mathrm{x}}$ emissions by the same amount as SNOx, we find that they have a much weaker impact on $\mathrm{OH}$ and $\tau_{\mathrm{CH}_{4}}$ and do not result in an increase in the $\mathrm{NO}_{\mathrm{x}}$ mixing ratio anywhere.
\end{abstract}

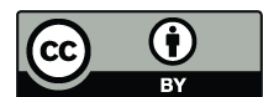

Correspondence to: J. Steinkamp (steinkam@mpch-mainz.mpg.de)

\section{Introduction}

Nitric oxide (NO) in the soil is produced by the microbial processes of nitrification and denitrification (Firestone and Davidson, 1989). The NO emission originates from a natural pool of nitrogen and a fraction from fertilizer application (Yienger and Levy II, 1995; Stehfest and Bouwman, 2006). The estimates of NO emitted yearly by soils (hereafter called SNOx) ranges from 4 to $21 \mathrm{Tg}(\mathrm{N})$ (Yienger and Levy II, 1995; Davidson and Kingerlee, 1997, and references therein). NO reacts rapidly with other atmospheric compounds, establishing an equilibrium between $\mathrm{NO}$ and nitric dioxide $\left(\mathrm{NO}_{2}\right)$. These two species are frequently refered to the oxides of nitrogen $\left(\mathrm{NO}_{\mathrm{x}}\right)$. Through reactions, deposition and stomatal uptake directly within the vegetation layer not all NO emitted by the soil escapes the canopy layer as $\mathrm{NO}_{\mathrm{x}}$ (Yienger and Levy II, 1995; Ganzeveld et al., 2002b). SNOx is topped by the anthropogenic combustion of fossil fuels $\left(20-24 \mathrm{Tg}(\mathrm{N}) \mathrm{yr}^{-1}\right)$ (Denman et al., 2007) and is comparable to the production of $\mathrm{NO}_{\mathrm{x}}$ from lightning and biomass burning, but especially in remote continental regions of the mid- and low-latitudes SNOx is the dominant source of $\mathrm{NO}_{\mathrm{x}}$. In this work SNOx refers to the flux from the canopy to the atmosphere. The fraction of $\mathrm{NO}_{\mathrm{x}}$ that reaches the atmosphere reacts as a catalyst for production of ozone $\left(\mathrm{O}_{3}\right)$, an important greenhouse gas. This $\mathrm{O}_{3}$ production is driven by the oxidation of carbon monoxide (CO) and volatile organic compounds (VOC), if the concentration of NO is higher than about 5-30 $\mathrm{pmol} \mathrm{mol}^{-1}$ (Brasseur et al., 1999). The unit used in this work is the molar (or "volume") mixing ratio as mol tracer per mol air (e.g. pmol mol-1). Atmospheric $\mathrm{NO}_{\mathrm{x}}$ is also involved in the production of the hydroxyl radical $(\mathrm{OH})$, which is responsible for the oxidation and depletion

Published by Copernicus Publications on behalf of the European Geosciences Union. 
of methane $\left(\mathrm{CH}_{4}\right)$, another greenhouse gas. Beyond these climate related issues, high $\mathrm{NO}_{\mathrm{x}}$ and $\mathrm{O}_{3}$ mixing ratios also have a direct impact on human health and on the vegetation (Sitch et al., 2007). $\mathrm{NO}_{\mathrm{x}}$ is removed from the atmosphere by reaction with hydroxyl radicals $(\mathrm{OH})$ or oxidation to dinitrogen pentaoxide $\left(\mathrm{N}_{2} \mathrm{O}_{5}\right)$ and subsequent deposition as nitric acid $\left(\mathrm{HNO}_{3}\right)$. It can also react with organic tracers to form peroxyl nitrates, mainly peroxyacetyl nitrate (PAN), which, once it is lifted to higher altitudes, can be transported over large distances releasing $\mathrm{NO}_{\mathrm{x}}$ when it is transported back downward again.

Previous model studies of the influence of SNOx on atmospheric chemistry mainly focused either on the $\mathrm{NO}_{\mathrm{x}}$ source itself, on $\mathrm{O}_{3}$, mostly on a regional scale. Ganzeveld et al. (2002a,b) investigate two different modeling approaches of the role of canopy processes on the effective exchange of $\mathrm{NO}_{\mathrm{x}}$ between the canopy and atmosphere. They concluded that the application of the big leaf approach with a separate treatment of dry deposition and biogenic emissions, in which the canopy reduction factor accounts for the fraction of these emission that escapes the canopy, provides a reasonable first order estimate of $\mathrm{NO}_{\mathrm{x}}$ canopy top fluxes. Jaeglé et al. (2005) examined the global partitioning of $\mathrm{NO}_{\mathrm{x}}$ sources using inverse modelling and the space-based $\mathrm{NO}_{2}$ column derived by GOME (Global Ozone Monitoring Experiment). Their a posteriori SNOx $\left(8.9 \mathrm{Tg}(\mathrm{N}) \mathrm{yr}^{-1}\right)$ is $68 \%$ greater than their a priori SNOx $\left(5.3 \mathrm{Tg}(\mathrm{N}) \mathrm{yr}^{-1}\right)$. Based on this, Jaeglé et al. (2005) suggest that the influence of $\mathrm{SNOx}$ on background $\mathrm{O}_{3}$ could be underestimated in current chemistry transport models (CTMs). Bertram et al. (2005) come to a similar conclusion by inverse modelling using another satellite sensor (SCIAMACHY) above the Western United States, computing an underestimation of $60 \%$. Delon et al. (2008) modelled higher $\mathrm{O}_{3}$ concentrations with higher SNOx above Western Africa. For Europe, Simpson (1995) found that SNOx hardly has any influence on controling the $\mathrm{O}_{3}$ mixing ratio. Isaksen and Hov (1987) already investigated the influence of changes in the emission intensity of different relevant trace gases on the oxidizing efficiency through an increase in $\mathrm{OH}$ concentration with increased $\mathrm{NO}_{\mathrm{x}}$ emissions, but they did not consider SNOx separately in their assessment. Fuglestvedt et al. (1999) demonstrate the importance of the geographical region of $\mathrm{NO}_{\mathrm{x}}$ sources for the changes in the ozone concentration and the oxidizing efficiency.

In this study, we take these analysis a step further and follow the reaction chain from $\mathrm{SNOx}$ through $\mathrm{O}_{3}$ and $\mathrm{OH}$ to its global influence on the oxidizing efficiency of the atmosphere. To do so, we compare two model runs with a state-ofthe-art 3-D global chemistry climate model. One is a simulation with all relevant emissions and reactions (BASE), and the second simulation is without SNOx (NOBIONO = "No biogenic NO"). We expect a considerable influence of SNOx on the mixing ratios and distribution of related global tropospheric trace gases $\left(\mathrm{NO}_{\mathrm{x}}, \mathrm{PAN}, \mathrm{HNO}_{3}, \mathrm{O}_{3}\right.$ and $\left.\mathrm{OH}\right)$. Furthermore the global oxidizing efficiency, indicated by the lifetime of $\mathrm{CH}_{4}\left(\tau_{\mathrm{CH}_{4}}\right)$, is expected to decrease $\left(\tau_{\mathrm{CH}_{4}}\right.$ increases) if we exclude $\mathrm{NO}_{\mathrm{x}}$ emission from soils. To investigate whether other surface $\mathrm{NO}_{\mathrm{x}}$ emissions result in similar effects, or if they differ due to differences in their distribution, we performed a third simulation (REDOTHER) in which we reduced the $\mathrm{NO}_{\mathrm{x}}$ emission from all other sources by the same amount as is emitted by the soils.

In the following section we briefly describe the model setup. We then compare the relevant tracer mixing ratios from the BASE simulation versus the NOBIONO and REDOTHER simulations. In the final section we present our conclusions and outlook.

\section{Model description and setup}

\subsection{General}

For this study the Modular Earth Submodel System version 1.6 (MESSy) coupled to the general circulation model ECHAM5 is employed. MESSy connects, through a standardized interface, submodels for different processes with bidirectional feedbacks (Jöckel et al., 2005, 2006). The combined system is refered to as the ECHAM5/MESSy atmospheric chemistry (EMAC) model. The meteorology for these simulations is driven by sea surface temperature (SST) from the AMIPIIb dataset (Taylor et al., 2000). The calculation of SNOx in the BASE simulation is based on the algorithm of Yienger and Levy II (1995), which is the most widely used SNOx algorithm in CTMs (Ganzeveld et al., 2002a; Jaeglé et al., 2005; Delon et al., 2008). This calculation is performed in the submodel ONLEM (Kerkweg et al., 2006b). $\mathrm{NO}_{\mathrm{x}}$ produced by lightning is calculated in the submodel LNOX $\left(1.6 \mathrm{Tg}(\mathrm{N}) \mathrm{yr}^{-1}\right)$. The remaining sources of $\mathrm{NO}_{\mathrm{x}}\left(43.5 \mathrm{Tg}(\mathrm{N}) \mathrm{yr}^{-1}\right)$ are read in from the offline EDGAR database (Olivier et al., 1994) by the submodel OFFLEM (Kerkweg et al., 2006b). NO emission from fossil fuel combustion, biomass and biofuel burning are combined and account for $43 \mathrm{Tg}(\mathrm{N}) \mathrm{yr}^{-1}$, while aircraft emit only $0.6 \mathrm{Tg}(\mathrm{N}) \mathrm{yr}^{-1}$. Other relevant emissions are calculated either by the ONLEM or OFFLEM submodel.

A model spinup time of eleven months (JanuaryNovember 1994) was chosen and the data of the period December 1994-Decmeber 1995 is analyzed here. To achieve an identical meteorology of both simulations feedback through trace gases and water vapor is switched off. Table 1 recapitulates the setup of the two simulations.

In the BASE simulation a yearly emission flux of $9.7 \operatorname{Tg}(\mathrm{N})$ was calculated. In the REDOTHER simulation the offline surface $\mathrm{NO}$ emission $\left(43 \mathrm{Tg}(\mathrm{N}) \mathrm{yr}^{-1}\right)$ are reduced globally by $22.5 \%$, which corresponds to $9.7 \mathrm{Tg}(\mathrm{N}) \mathrm{yr}^{-1}$.

\subsection{Soil NO emission algorithm}

The emission of NO from soils is calculated based on the algorithm developed by Yienger and Levy II (1995) and 
Table 1. Setup of the ECHAM5/MESSy model and applied submodels.

\begin{tabular}{|c|c|c|}
\hline Horizontal resolution & $\mathrm{T} 42\left(\sim 2.8^{\circ} \times 2.8^{\circ}\right)$ & \\
\hline Vertical resolution & $\mathrm{L} 31$ (up to $10 \mathrm{hPa}$ ) & \\
\hline Internal timestep & $20 \mathrm{~min}$ & \\
\hline Timestep of output & $5 \mathrm{~h}$ & \\
\hline Period of simulation & 1994-1995 & \\
\hline Used submodels & Calculation of & Literature ref. \\
\hline CLOUD & Clouds and precipitation & Jöckel et al. (2006) \\
\hline CONVECT & Convection & Tost et al. (2006b) \\
\hline CVTRANS & Convective tracer transport & Tost (2006) \\
\hline DRYDEP & Dry deposition & Kerkweg et al. (2006a) \\
\hline JVAL & Rates of photolysis & Jöckel et al. (2006) \\
\hline LNOX & Lightning $\mathrm{NO}_{\mathrm{x}}$ & Tost et al. (2007) \\
\hline MECCA & Chemical atmospheric reactions ${ }^{\mathrm{a}}$ & Sander et al. (2005) \\
\hline OFFLEM $^{\mathrm{b}}$ & Offline emissions & Kerkweg et al. (2006b) \\
\hline ONLEM $^{\mathrm{c}}$ & Online emissions & Kerkweg et al. (2006b) \\
\hline RAD4ALL & Radiation & Jöckel et al. (2006) \\
\hline SCAV & Wet deposition & Tost et al. (2006a) \\
\hline TNUDGE & Tracer nudging & Kerkweg et al. (2006b) \\
\hline TROPOP & Calculation of the tropopause & Jöckel et al. (2006) \\
\hline
\end{tabular}

a Tropospheric reaction with NMHC and without halogens.

$\mathrm{b}$ Biomass burning and fossil fuel NO emission reduced in REDOTHER.

${ }^{c}$ Soil NO emissions switched off in NOBIONO simulation.

depends on ecosystem type, soil moisture state and the surface temperature. Our underlying ecosystem map is compiled from Olson (1992) (Ganzeveld et al., 2006), which 72 ecosystem classes have been reduced to the twelve ecosystems defined by Yienger and Levy II (1995), with corresponding dry and wet emission factors (Table 2). Agriculture and (tropical) rainforest is treated separately. In the original algorithm the precipitation history is used to distinguish between the dry and wet soil moisture state. In our implementation we define the dry state to be when the soil moisture is below $10 \%$ volumetric soil moisture and wet above $10 \%$. The temperature dependence is calculated according to Eq. (1) for wet soil conditions and (2) for dry soil conditions.

$F_{\mathrm{NO}}\left(T, A_{w}\right)= \begin{cases}0,28 \cdot T \cdot A_{w} & 0^{\circ} \mathrm{C}<T \leq 10^{\circ} \mathrm{C} \\ e^{0,103 \cdot T} \cdot A_{w} & 10^{\circ} \mathrm{C}<T \leq 30^{\circ} \mathrm{C} \\ 21,97 \cdot A_{w} & T>30^{\circ} \mathrm{C}\end{cases}$

$F_{\mathrm{NO}}\left(T, A_{d}\right)=\left\{\begin{array}{lr}\frac{T}{30} \cdot A_{d} 0^{\circ} \mathrm{C}<T \leq 30^{\circ} \mathrm{C} \\ A_{d} \quad T>30^{\circ} \mathrm{C}\end{array}\right.$

In the rainforest Yienger and Levy II (1995) assumed SNOx to be constant: a dry emission factor is applied for the five driest months (Northern Hemisphere: May-September, Southern Hemisphere: November-March) and a wet emission factor for the remaining seven months. For agricultural areas wet grassland conditions are assumed for the whole year. On top of that, fertilizer induced emission based on Bouwman and Boumans (2002) is added.
Table 2. Ecosystems and emission factors according to Yienger and Levy II (1995).

\begin{tabular}{rlll}
\hline & & \multicolumn{2}{c}{ emission factor } \\
& Ecosystem & wet $\mathrm{A}_{w, e}$ & dry $\mathrm{A}_{d, e}$ \\
\hline 1 & water & 0 & 0 \\
2 & ice & 0 & 0 \\
3 & desert & 0 & 0 \\
4 & scrubland & 0 & 0 \\
5 & tundra & 0.05 & 0.37 \\
6 & grassland & 0.36 & 2.65 \\
7 & woodland & 0.17 & 1.44 \\
8 & decidous forest & 0.03 & 0.22 \\
9 & coniferous forest & 0.03 & 0.22 \\
10 & dry decidous forest & 0.06 & 0.4 \\
11 & rainforest & 2.6 & 8.6 \\
12 & agriculture & 0 & 0 \\
\hline
\end{tabular}

If, after a certain period of dryness, the soil receives a sufficient amount of precipitation a burst of $\mathrm{NO}$ emission occurs. Based on the precipitation history of the last 14 days and if the soil moisture state is defined as dry, this burst is implemented as pulsing factor, depending on the amount of precipitation during the last day (Eq. 3) and lasting for $d$ days. 


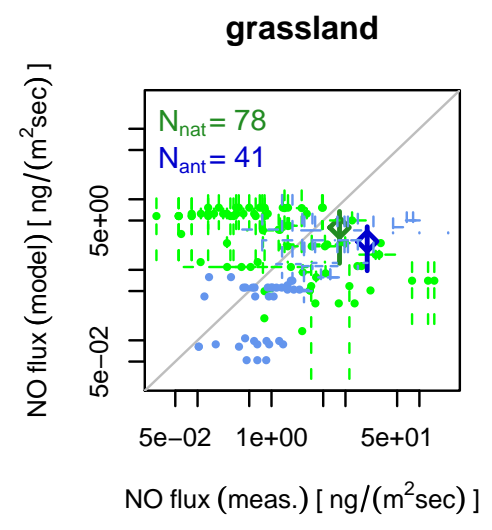

decidous forest

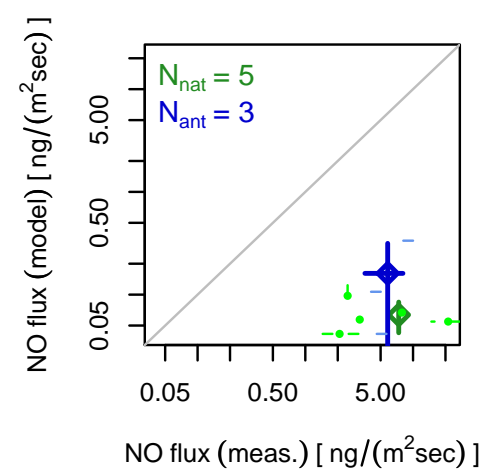

coniferous forest

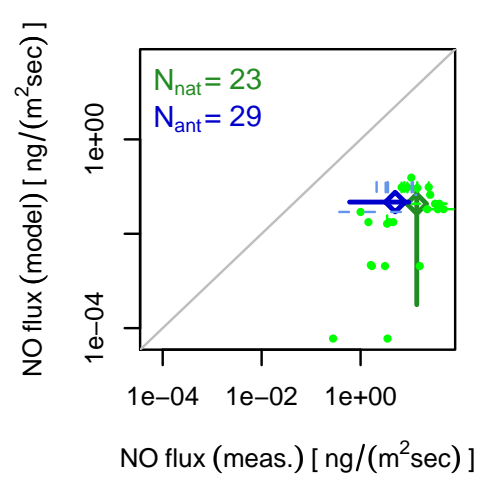

dry decidous forest

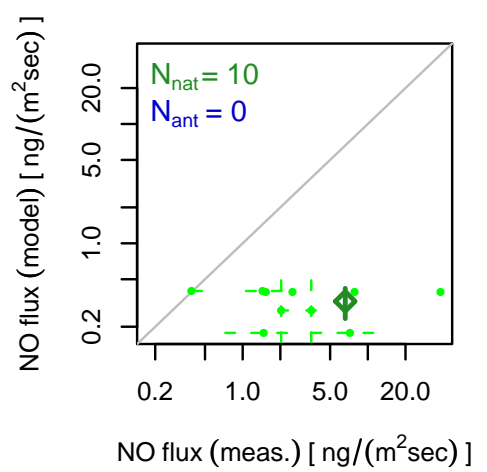

rainforest

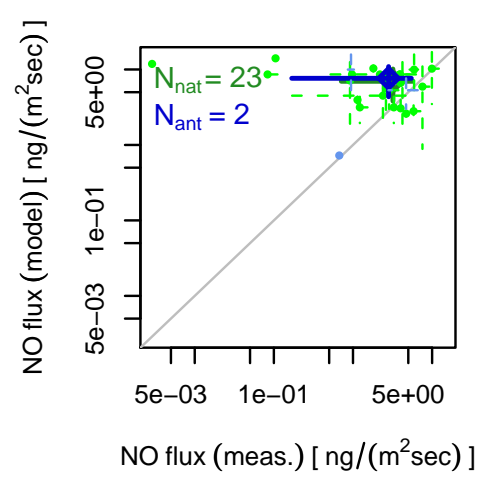

agriculture

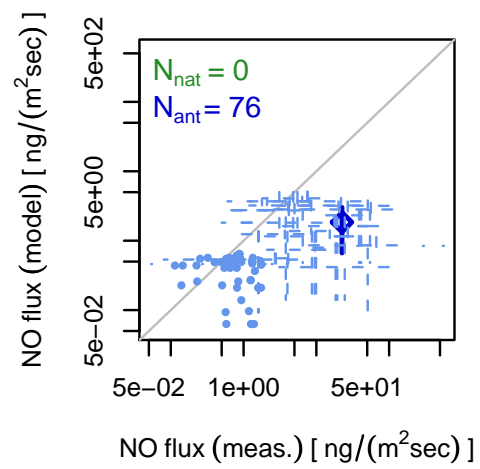

Fig. 1. Scatterplots of measured versus modeled NO emission flux from soils in different ecosystems. Measurements under natural conditions are colored in green and anthropogenicaly influenced measurements are in blue, mean and standard deviation slightly darker.

If this pulse is not active, the pulsing factor equals one.

pulse $= \begin{cases}11,19 \cdot e^{-0,805 \cdot d} & 1<d<3 ; \quad 1-5 \frac{\mathrm{mm}}{\mathrm{day}} \\ 14,68 \cdot e^{-0,384 \cdot d} & 1<d<7 ; 5-15 \frac{\mathrm{mm}}{\mathrm{day}} \\ 18,46 \cdot e^{-0,208 \cdot d} & 1<d<14 ; \quad>15 \frac{\mathrm{mm}}{\mathrm{day}}\end{cases}$

This is the direct modeled SNOx. Within the vegetation layer the $\mathrm{NO}$ emitted by the soil rapidly reacts to $\mathrm{NO}_{2}$ and is partly deposited back on the vegetation and the ground. This is reflected by the canopy reduction factor $(\mathrm{CRF}, 0 \leq \mathrm{CRF} \leq 1)$, calculated depending on the leaf area index (LAI) and the stomatal area index (SAI).

The NO flux reaching the atmosphere is therefore calculated as:

flux $=\mathrm{CRF} \cdot$ pulse $\cdot F_{\mathrm{NO}}\left(T, A_{d / w}\right)$

We have made a preliminary comparison of the model simulated soil NO emissions versus measurements for the period 1990 to 2000 without canopy reduction (Steinkamp, 2007). Figure 1 shows an overview of these comparisons. We found that the yearly averaged flux in the tropics compares well with measurements, whereas the fluxes in temperate regions seem to be underestimated. Since the applied algorithm is empirically based, comparison on a point by point basis are not appropriate, but the overall distribution can be compared, in general the emission flux tends to be underestimated in all ecosystems, except for the rainforest.

\section{Results and discussion}

The emissions of NO from soils in the BASE simulation accounts for $18 \%$ of the total annual global NO emissions (Table 3). The interannual variability of SNOx is low in the model (Steinkamp, 2007). The largest SNOx emissions are calculated for tropical regions. During JJA there are some exceptions further north in Northern America, Europe and North-Eastern China. These are fertilizer induced emissions in agricultural regions (Fig. 2 and Table 3).

The data is analyzed by season with a focus on the winter and summer season. There is a notable seasonal variation with larger SNOx in the summer period of each hemisphere and with a larger contribution of SNOx to the total NO emissions during the northern hemispheric spring and summer (Table 3 ). The first point can be explained by the temperature dependence of SNOx and the second one by the greater landmasses in the Northern Hemisphere. In the 
Table 3. Simulated total $\mathrm{NO}_{\mathrm{x}}$ emissions, $\mathrm{SNOx}$ in $\mathrm{Tg}(\mathrm{N})$ in the BASE simulation and in brackets relative contribution of $\mathrm{SNOx}$ to the total NO emissions for different regions and periods.

\begin{tabular}{|c|c|c|c|c|c|c|c|c|}
\hline \multirow[b]{3}{*}{ Season $^{\mathrm{a}}$} & \multirow{2}{*}{\multicolumn{2}{|c|}{ Global }} & \multirow{2}{*}{\multicolumn{2}{|c|}{$\begin{array}{l}\text { Low-latitudes } \\
\left(30^{\circ} \mathrm{N}-30^{\circ} \mathrm{S}\right)\end{array}$}} & \multicolumn{4}{|c|}{ Mid-latitudes } \\
\hline & & & & & \multicolumn{2}{|c|}{$\left(30^{\circ} \mathrm{N}-60^{\circ} \mathrm{N}\right)$} & \multicolumn{2}{|c|}{$\left(30^{\circ} \mathrm{S}-60^{\circ} \mathrm{S}\right)$} \\
\hline & total & soil & total & soil & total & soil & total & soil \\
\hline DJF & 13.08 & $1.78(14 \%)$ & 7.64 & $1.60(21 \%)$ & 4.94 & $0.06(1 \%)$ & 0.46 & $0.12(26 \%)$ \\
\hline MAM & 13.42 & $2.38(18 \%)$ & 7.27 & $1.72(24 \%)$ & 5.68 & $0.59(10 \%)$ & 0.42 & $0.07(17 \%)$ \\
\hline JJA & 15.26 & $3.35(23 \%)$ & 7.72 & $1.76(23 \%)$ & 7.04 & $1.64(23 \%)$ & 0.33 & $0.03(10 \%)$ \\
\hline SON & 14.84 & $2.13(14 \%)$ & 8.75 & $1.70(19 \%)$ & 5.61 & $0.36(6 \%)$ & 0.40 & $0.07(18 \%)$ \\
\hline All & 54.79 & $9.74(18 \%)$ & 29.90 & $6.78(23 \%)$ & 22.99 & $2.65(12 \%)$ & 1.58 & $0.30(19 \%)$ \\
\hline
\end{tabular}

${ }^{\text {a DJF }}=$ December 1994, January, February 1995; MAM = March, April, May 1995; JJA = June, July, August 1995; SON = September, October, November 1995

northern mid-latitudes SNOx plays a less important role relative to other $\mathrm{NO}_{\mathrm{x}}$ emissions, except during the JJA period.

\subsection{Influence of NO emissions on related trace gases}

The column mean mixing ratios of $\mathrm{NO}_{\mathrm{x}}, \mathrm{PAN}, \mathrm{HNO}_{3}$ and $\mathrm{O}_{3}$ and the column mean concentration of $\mathrm{OH}$ in the gridcells (weighted by the air mass in the gridcells) in the lower troposphere (below $500 \mathrm{hPa}$; hereafter "LT") from the BASE simulation are compared with the values from the NOBIONO and REDOTHER simulations in this section. Here we first consider the overall correlations between the changes in the trace gas columns and the SNOx distribution (Table 4), then we discuss the changes in the individual gases in the following subsections.

As expected, in the surface layer (hereafter "SL") as well as in the LT the difference between the $\mathrm{NO}_{\mathrm{x}}$ column mean mixing ratio in the NOBIONO simulation versus the BASE simulation is well-correlated with SNOx in all regions (Table 4; scatterplots are included in the supplement http://www.atmos-chem-phys.net/9/2663/2009/ acp-9-2663-2009-supplement.pdf). A low correlation is computed for the Northern Hemisphere LT during DJF, as expected due to the small SNOx compared to the anthropogenic emissions.

There is hardly any correlation in the low-latitudes and in the northern mid-latitudes of SNOx and the difference in the column mean mixing ratio of PAN in the two simulations (Table 4). In contrast, there is a better correlation in the southern mid-latitudes between the difference in the LT PAN column mixing ratio and SNOx. This suggests a dominating role of SNOx in the formation of PAN in the mid-latitudes of the Southern Hemisphere. The other precursor of PAN, peroxyacyl radicals, depend on the photooxidation of VOCs, which in turn depends on $\mathrm{O}_{3}$ and $\mathrm{OH}$ (Roberts et al., 2001; Cleary et al., 2007). At low latitudes, convective updrafts and subsiding airmasses, combined with the strong temperature dependence of the decomposition of PAN decreases the correlation.
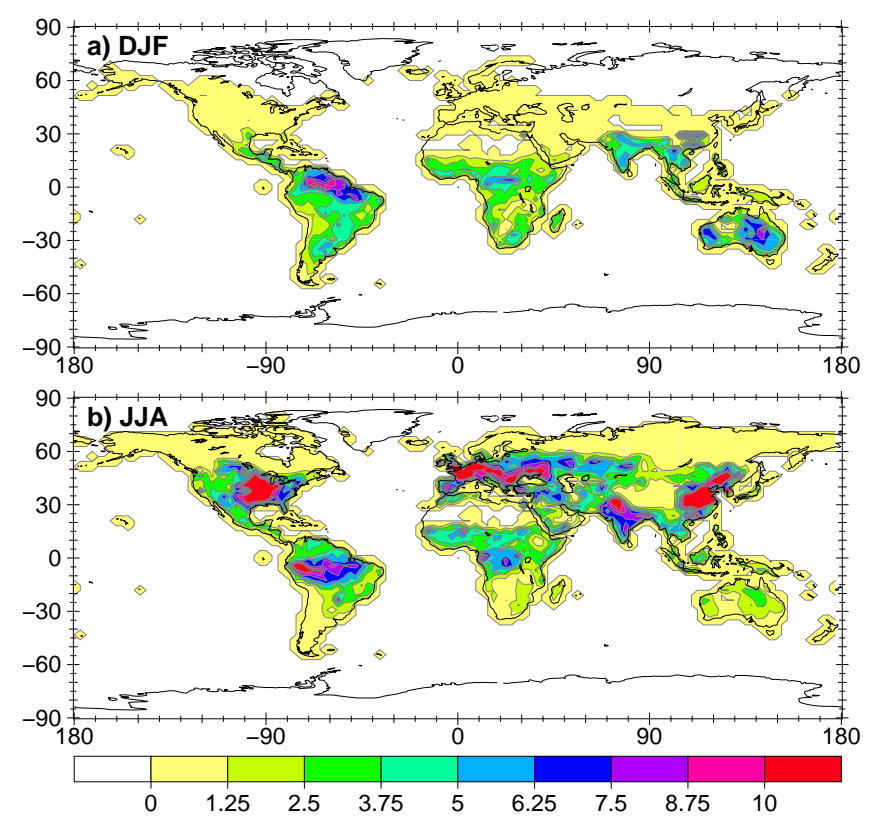

Fig. 2. Simulated SNOx flux for (a) December 1994 to February 1995 and (b) June to August 1995 in $\frac{\mathrm{ng}}{\mathrm{m}^{2} \mathrm{sec}}$.

The correlation between SNOx and the difference in the LT $\mathrm{O}_{3}$ column mean mixing ratio is lower than for $\mathrm{NO}_{\mathrm{x}}$. This is partly due to the longer lifetime of $\mathrm{O}_{3}$, which is better mixed in the LT. Furthermore the production of $\mathrm{O}_{3}$ is not only determined by the $\mathrm{NO}_{\mathrm{x}}$ mixing ratio, but also by the concentration of VOC. The correlation of the $\mathrm{OH}$ column mean concentration difference in the LT with SNOx is similar to $\mathrm{O}_{3}$. $\mathrm{OH}$ is a very short lived tracer, whose production depends mainly on: 1.) the photolysis of $\mathrm{O}_{3}$ and the water vapor concentration in the lower troposphere, 2.) the reaction of $\mathrm{NO}$ with $\mathrm{HO}_{2}$ in the upper troposphere and 3.) the reaction of $\mathrm{O}_{3}$ with $\mathrm{HO}_{2}$ (Fig. 3). This results, depending on the dominating reaction, in a higher or lower correlation of the $\mathrm{OH}$ column concentration difference versus SNOx than the 
Table 4. Correlation coefficient $\left(R^{2}\right)$ between surface SNOx flux values and the difference (NOBIONO-BASE) of the tracer burden in the overlying model surface layer (SL) lower troposphere (LT; $>500 \mathrm{hPa}$ ) by gridcell, averaged over the corresponding period; only gridcells with a land surface fraction of at least $75 \%$ were included.

\begin{tabular}{|c|c|c|c|c|c|c|c|c|c|c|}
\hline \multirow[t]{3}{*}{ Season $^{\mathrm{a}}$} & \multicolumn{2}{|c|}{$\mathrm{NO}_{\mathrm{x}}$} & \multicolumn{2}{|c|}{ PAN } & \multicolumn{2}{|c|}{$\mathrm{HNO}_{3}$} & \multicolumn{2}{|c|}{$\mathrm{O}_{3}$} & \multicolumn{2}{|c|}{$\mathrm{OH}$} \\
\hline & SL & $\mathrm{LT}$ & SL & LT & SL & LT & SL & LT & SL & LT \\
\hline & \multicolumn{10}{|c|}{ Global $(N=2462)$} \\
\hline DJF & 0.82 & 0.83 & 0.54 & 0.43 & 0.41 & 0.46 & 0.44 & 0.53 & 0.48 & 0.51 \\
\hline MAM & 0.90 & 0.88 & 0.42 & 0.34 & 0.56 & 0.52 & 0.31 & 0.40 & 0.41 & 0.49 \\
\hline JJA & 0.90 & 0.87 & 0.30 & 0.22 & 0.50 & 0.33 & 0.15 & 0.26 & 0.24 & 0.35 \\
\hline SON & 0.88 & 0.89 & 0.54 & 0.42 & 0.49 & 0.42 & 0.44 & 0.52 & 0.47 & 0.60 \\
\hline \multirow[t]{2}{*}{ Year } & 0.92 & 0.89 & 0.48 & 0.37 & 0.56 & 0.46 & 0.32 & 0.43 & 0.38 & 0.53 \\
\hline & \multicolumn{10}{|c|}{ Low-latitudes, $30^{\circ} \mathrm{N}-30^{\circ} \mathrm{S}(N=646)$} \\
\hline DJF & 0.68 & 0.66 & 0.19 & 0.14 & 0.15 & 0.15 & 0.12 & 0.16 & 0.14 & 0.14 \\
\hline MAM & 0.79 & 0.75 & 0.16 & 0.05 & 0.41 & 0.31 & 0.08 & 0.11 & 0.19 & 0.18 \\
\hline JJA & 0.72 & 0.77 & 0.28 & 0.18 & 0.16 & 0.08 & 0.17 & 0.22 & 0.07 & 0.23 \\
\hline SON & 0.75 & 0.78 & 0.26 & 0.15 & 0.18 & 0.08 & 0.12 & 0.14 & 0.09 & 0.18 \\
\hline \multirow{2}{*}{ Year } & 0.81 & 0.78 & 0.25 & 0.15 & 0.23 & 0.11 & 0.09 & 0.14 & 0.06 & 0.21 \\
\hline & \multicolumn{10}{|c|}{ Northern mid-latitudes, $30^{\circ} \mathrm{N}-60^{\circ} \mathrm{N}(N=637)$} \\
\hline DJF & 0.83 & 0.30 & 0.03 & 0.01 & 0.51 & 0.37 & 0.03 & 0.11 & 0.06 & 0.37 \\
\hline MAM & 0.92 & 0.90 & 0.03 & 0.13 & 0.43 & 0.32 & 0.00 & 0.10 & 0.04 & 0.22 \\
\hline JJA & 0.91 & 0.85 & 0.06 & 0.02 & 0.43 & 0.20 & 0.00 & 0.03 & 0.07 & 0.12 \\
\hline SON & 0.90 & 0.81 & 0.13 & 0.12 & 0.59 & 0.49 & 0.10 & 0.23 & 0.20 & 0.35 \\
\hline \multirow[t]{2}{*}{ Year } & 0.93 & 0.89 & 0.04 & 0.04 & 0.44 & 0.26 & 0.00 & 0.06 & 0.07 & 0.17 \\
\hline & \multicolumn{10}{|c|}{ Southern mid-latitudes, $30^{\circ} \mathrm{S}-60^{\circ} \mathrm{S}(N=46)$} \\
\hline DJF & 0.95 & 0.88 & 0.40 & 0.47 & 0.73 & 0.78 & 0.69 & 0.75 & 0.40 & 0.72 \\
\hline MAM & 0.94 & 0.90 & 0.76 & 0.75 & 0.68 & 0.68 & 0.72 & 0.77 & 0.59 & 0.78 \\
\hline JJA & 0.72 & 0.78 & 0.59 & 0.56 & 0.36 & 0.36 & 0.33 & 0.64 & 0.46 & 0.78 \\
\hline SON & 0.95 & 0.89 & 0.78 & 0.71 & 0.51 & 0.61 & 0.77 & 0.78 & 0.61 & 0.83 \\
\hline Year & 0.95 & 0.90 & 0.74 & 0.73 & 0.69 & 0.73 & 0.77 & 0.80 & 0.54 & 0.82 \\
\hline
\end{tabular}

a See Table 3 for abbreviations.

correlation for the $\mathrm{O}_{3}$ column mixing ratio difference versus SNOx. The correlation of the changes in the mixing ratios of $\mathrm{O}_{3}$ and $\mathrm{OH}$ versus SNOx is lower in the SL than in the LT. Due to the longer lifetime of $\mathrm{O}_{3}$ compared to $\mathrm{NO}_{\mathrm{x}}$, the $\mathrm{O}_{3}$ distribution depends more on transport away from the source regions. The horizontal transport explains the lower correlation compared to $\mathrm{NO}_{\mathrm{x}}$ and vertical transport can explain the higher correlation in the column compared to the SL.

\subsection{1 $\mathrm{NO}_{\mathrm{x}}$}

The global mean mixing ratio of $\mathrm{NO}_{\mathrm{x}}$ in the LT during DJF decreases by $7 \%$ in the NOBIONO simulation compared to the BASE simulation. During JJA it decreases by $17 \%$. In both cases the decrease in the mixing ratio is less than the contribution of SNOx (14\% and 23\%, respectively). The maximum decrease is $81 \%$ in DJF and $78 \%$ in JJA, while the maximum absolute decreases in the DJF and JJA periods are 365 and $319 \mathrm{pmol} \mathrm{mol}^{-1}$, re- spectively (figures with absolute differences can be found in the supplement http://www.atmos-chem-phys.net/9/2663/ 2009/acp-9-2663-2009-supplement.pdf). Interestingly, during DJF the mixing ratio above large parts of the Northern Hemisphere increases, by up to 7\% (Fig. 4a) in the NOBIONO simulation, with the largest absolute increase of $12.3 \mathrm{pmol} \mathrm{mol}^{-1}$ above Europe. In the JJA period the maximum relative increase of $7.6 \%$ is larger than in the DJF period, but the maximum absolute difference is only $7.0 \mathrm{pmol} \mathrm{mol}^{-1}$ (Fig. 4b).

A similar result has been noted for model sensitivity simulations with and without $\mathrm{NO}_{\mathrm{x}}$ from lightning (Stockwell et al., 1999; Labrador et al., 2005), in which a decrease in near-surface $\mathrm{NO}_{\mathrm{x}}$ mixing ratios was computed for similar regions with increasing production of $\mathrm{NO}_{\mathrm{x}}$ by lightning. Although $\mathrm{NO}_{\mathrm{x}}$ produced by lightning is formed in the free troposphere and SNOx originates from the surface, we achieve comparable results with $\mathrm{SNOx}$ as with lightning $\mathrm{NO}_{\mathrm{x}}$ by 

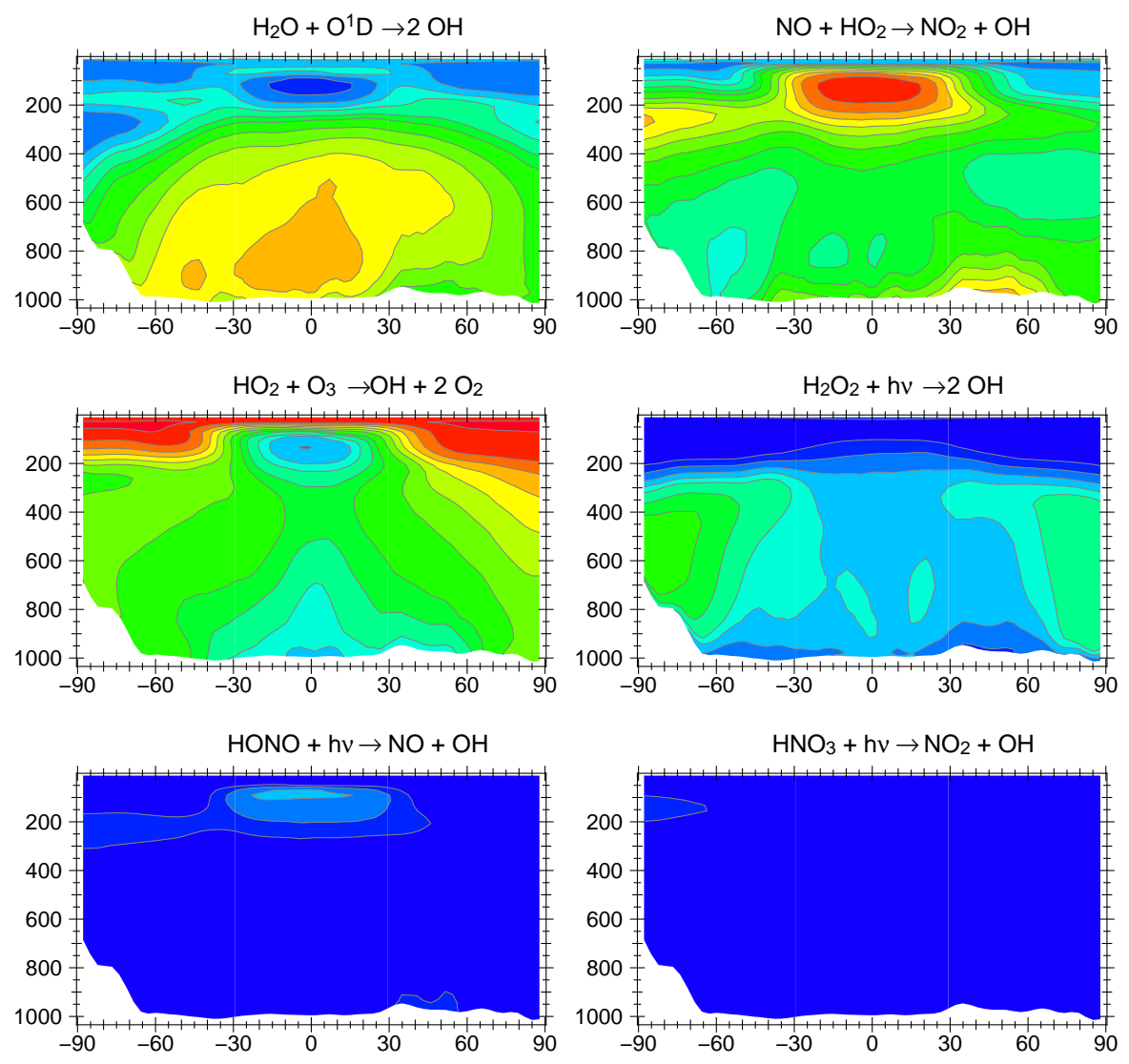

$\mathrm{HNO}_{4}+\mathrm{hv} \rightarrow .667\left(\mathrm{NO}_{2}+\mathrm{HO}_{2}\right)+.333\left(\mathrm{NO}_{3}+\mathrm{OH}\right)$

$\mathrm{CH}_{3} \mathrm{OOH}+\mathrm{O}_{2}+\mathrm{hv} \rightarrow \mathrm{HCHO}+\mathrm{OH}+\mathrm{HO}_{2}$

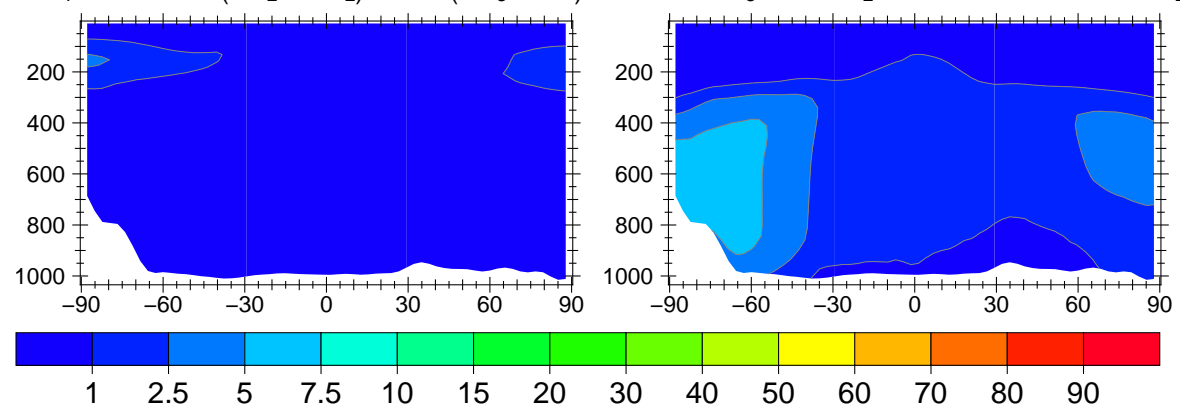

Fig. 3. Zonal mean relative contribution of the eight major $\mathrm{OH}$ producing reactions in the BASE simulation integrated over one year.

Labrador et al. (2005). To explain why the $\mathrm{NO}_{\mathrm{x}}$ mixing ratio decreases less than the relative decrease in the emission of the NOBIONO simulation compared to the BASE simulation, and why it even increases during the DJF period in large areas in the Northern Hemisphere, the feedback through $\mathrm{O}_{3}$ and $\mathrm{OH}$ has to be taken into account. Stockwell et al. (1999) assumed that the general increase in $\mathrm{O}_{3}$ with lightning $\mathrm{NO}_{\mathrm{x}}$ causes an increase in $\mathrm{OH}$. This $\mathrm{OH}$ reduces the lifetime of $\mathrm{NO}_{\mathrm{x}}\left(\tau_{\mathrm{NO}_{\mathrm{x}}}\right)$ through Reaction (R1) above regions with high non-lightning $\mathrm{NO}_{\mathrm{x}}$ sources. Labrador et al. (2005) showed that the conversion to $\mathrm{HNO}_{3}$ via $\mathrm{N}_{2} \mathrm{O}_{5}$ also contributes to the shorter $\tau_{\mathrm{NO}_{\mathrm{x}}}$ (Reaction R2) with higher $\mathrm{NO}_{\mathrm{x}}$ emissions.

$\mathrm{NO}_{2}+\mathrm{OH} \rightarrow \mathrm{HNO}_{3}$

$$
\begin{aligned}
\mathrm{NO}_{2}+\mathrm{O}_{3} & \rightarrow \mathrm{NO}_{3}+\mathrm{O}_{2} \\
\mathrm{NO}_{3}+\mathrm{NO}_{2} & \rightarrow \mathrm{N}_{2} \mathrm{O}_{5} \\
\mathrm{~N}_{2} \mathrm{O}_{5}+\mathrm{H}_{2} \mathrm{O} & \rightarrow 2 \mathrm{HNO}_{3} \\
2 \mathrm{NO}_{2}+\mathrm{O}_{3}+\mathrm{H}_{2} \mathrm{O} & \rightarrow 2 \mathrm{HNO}_{3}+\mathrm{O}_{2}
\end{aligned}
$$

Similarly we find that without $\mathrm{SNOx}, \mathrm{O}_{3}$ and $\mathrm{OH}$ levels decrease over large regions due to the longer $\mathrm{O}_{3}$ lifetime, resulting in enhanced $\tau_{\mathrm{NO}_{\mathrm{x}}}$, and due to Reactions (R1) and (R2) the $\mathrm{NO}_{\mathrm{x}}$ mixing ratio increases in some regions with low SNOx. The changes in $\mathrm{HNO}_{3}, \mathrm{O}_{3}$ and $\mathrm{OH}$ related to this are discussed in the following sections. 

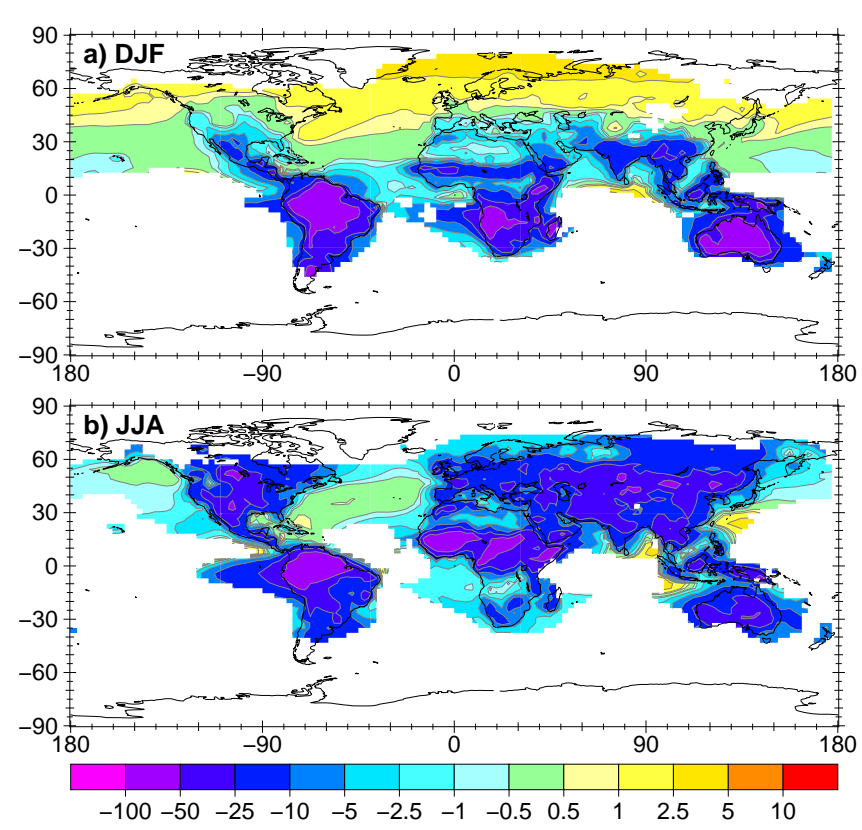

Fig. 4. Relative difference ( $\left.\frac{\text { NOBIONO-BASE }}{\text { BASE }} * 100 \%\right)$ of the lower tropospheric mixing ratio of $\mathrm{NO}_{\mathrm{x}}$ in $\%$ (regions with values below $30 \mathrm{pmol} \mathrm{mol}^{-1}$ in the BASE simulation are excluded from the calculation) averaged for (a) December, January, February and (b) June, July and August.

In the vertical direction the strongest effects of SNOx are simulated near the surface (DJF: 59\%, JJA: 55\%), and a decrease of up to 10 to $25 \%$ at higher altitudes in the zonal mean is calculated when SNOx is switched off (Fig. 5). The effect of convective transport to higher altitudes has a stronger influence on the difference in the total burden between 500 and $250 \mathrm{hPa}$ during DJF (relative: $11.3 \%$, absolute: $1.6 \mathrm{Gg}$ ) than during JJA (relative: $9.0 \%$, absolute: $1.1 \mathrm{Gg}$ ). This is because the main regions where the convective transport is most effective are in the Southern Hemisphere, especially the Amazon Basin and the southern tropics of Africa (not shown). In the REDOTHER simulation the relative decrease between 500 and $250 \mathrm{hPa}$ is much smaller (DJF: 5.2\%, JJA: 2.9\%).

The reduction of all remaining surface emissions in the REDOTHER simulation leads to a decrease in the LT $\mathrm{NO}_{\mathrm{x}}$ mixing ratio of $19 \%$ during DJF and $12 \%$ during JJA compared to the BASE simulation. A small relative increase, by less than $1 \%$, occurs only in oceanic regions where the absolute mixing ratio is below $30 \mathrm{pmol} \mathrm{mol}^{-1}$. The main decreases are located above the (northern hemispheric) land surfaces (Fig. 6). In the zonal mean the maximum extent of the relative decrease is located closer to the surface, because the major changes are outside the tropics and are not lifted as effectively by deep convection (Fig. 7).
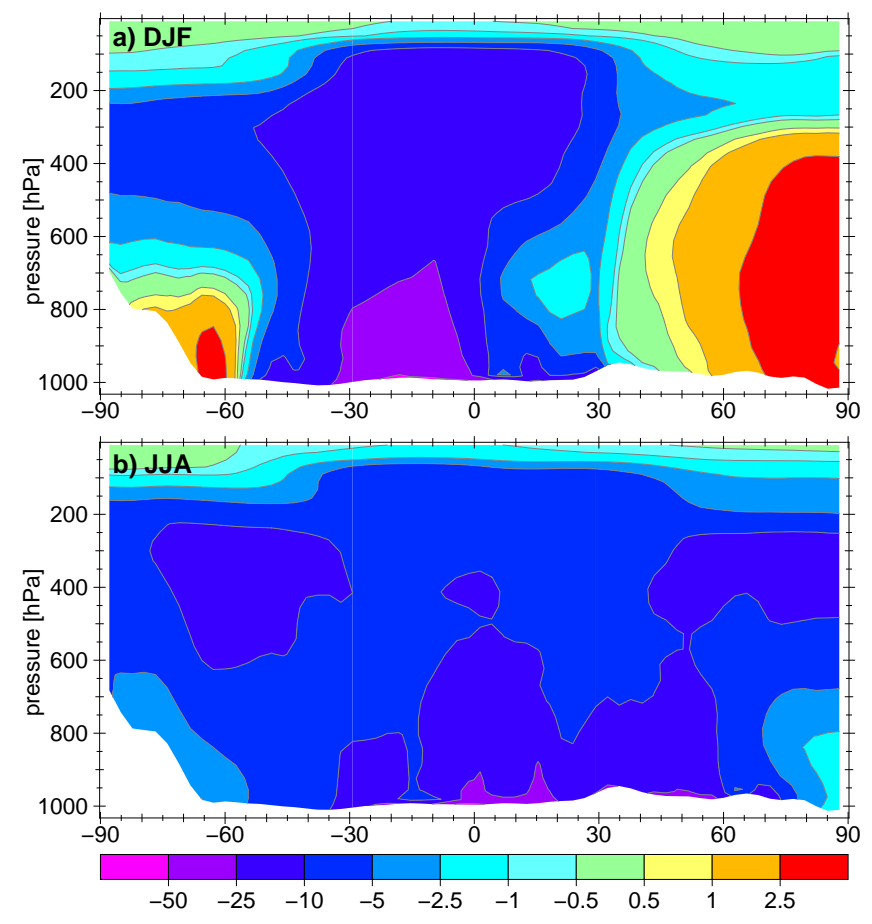

Fig. 5. Zonal mean relative difference ( $\frac{\text { NOBIONO-BASE }}{\text { BASE }} * 100 \%$ ) of the $\mathrm{NO}_{\mathrm{x}}$ mixing ratio in $\%$ averaged for (a) December, January, February and (b) June, July and August. Note that the y-axis is linearly scaled, since the focus of this work lies in the lower troposphere.

\subsubsection{PAN}

The LT PAN mixing ratio decreases globally by $4 \%$ during DJF and 10\% during JJA without SNOx. In both periods the PAN mixing ratio decreases nearly everywhere above the continents (Fig. 8). Above the tropical oceans, especially during JJA, there is a high relative but a negligible absolute increase in the PAN mixing ratio associated with a decrease in SNOx. As mentioned above, the formation of PAN in the northern mid- and low latitudes relies more on other trace gases than on SNOx, but more on SNOx in the southern midlatitudes. This explains the larger decrease during DJF than during JJA. There is also no increase of PAN in the Northern Hemisphere during DJF despite higher $\mathrm{NO}_{\mathrm{x}}$ mixing ratios, which confirms a dominating role of VOC in PAN formation.

Interestingly, in the upper troposphere between $500 \mathrm{hPa}$ and $250 \mathrm{hPa}$ the largest decrease in the PAN mixing ratio is during DJF (6.5\%), whereas it is 5.1\% during JJA. In the zonal mean of the relative difference in PAN mixing ratio with and without SNOx (Fig. 9), the effect of convective transport in the lower latitudes is more effective during DJF than during JJA. At the higher altitudes PAN does not increase anymore, due to its longer lifetime resulting in better mixing. In the REDOTHER simulation the decrease (DJF: $4.1 \%$, JJA: $1.4 \%$ ) is smaller between 500 and $250 \mathrm{hPa}$. 

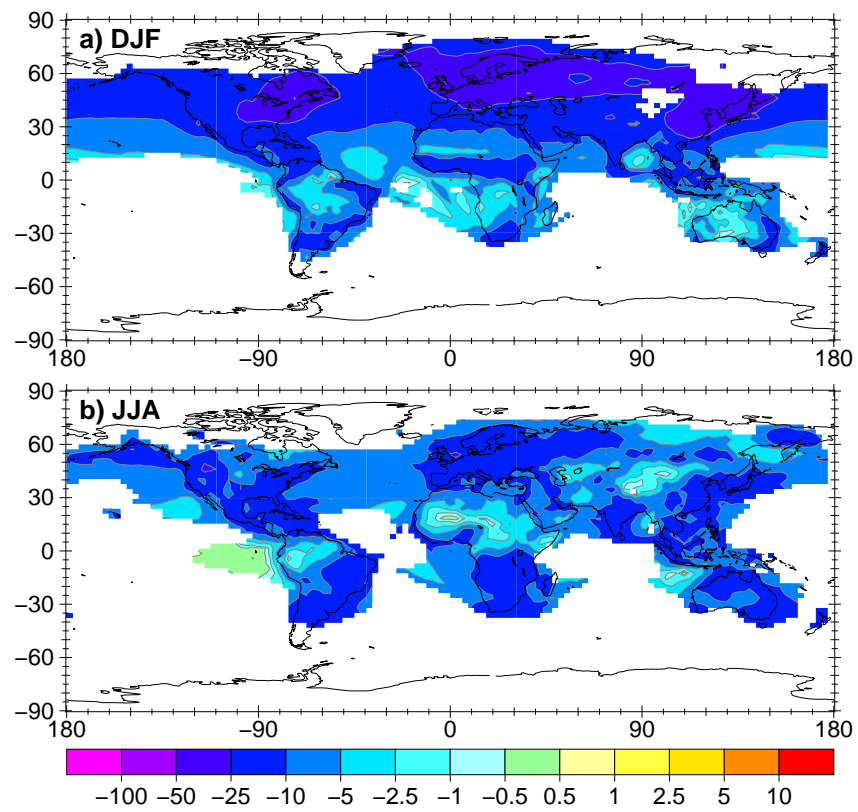

Fig. 6. Relative difference ( $\frac{\text { REDOTHER-BASE }}{\mathrm{BASE}} * 100 \%$ ) of the lower tropospheric mixing ratio of $\mathrm{NO}_{\mathrm{x}}$ in \% (regions with values below $30 \mathrm{pmol} \mathrm{mol}^{-1}$ in the BASE simulation are excluded from the calculation) averaged for (a) December, January, February and (b) June, July and August.

The differences in the PAN mixing ratio should be interpreted with caution, because the model generally overestimates its levels compared to observations (Jöckel et al., 2006), though this may improve with a new isoprene oxidation scheme (Taraborrelli et al., 2008).

\subsection{3 $\mathrm{HNO}_{3}$}

The global LT mean mixing ratio of $\mathrm{HNO}_{3}$ decreases by $15 \%$ (DJF) and 19\% (JJA) without SNOx. The greatest decrease occurs above continental regions of the low-latitudes and in the summer months in the Northern Hemisphere (Fig. 10). The amplified decrease in the mixing ratio of $\mathrm{HNO}_{3}$ compared to the decrease of $\mathrm{NO}_{\mathrm{x}}$ mixing ratio is because the formation of $\mathrm{HNO}_{3}$ is not only determined by the $\mathrm{NO}_{\mathrm{x}}$ mixing ratio, but also relies on the mixing ratios of $\mathrm{O}_{3}$ and $\mathrm{OH}$, which also decrease, as discussed in the following sections.

Nitric acid is mainly deposited on aerosol particles, taken up by cloud water or directly deposited on the earth's surface. The deposition of $\mathrm{HNO}_{3}$ is decreased by $18 \%$ throughout the year without SNOx. During DJF the decrease is $15 \%$ and during JJA it is $25 \%$. In the REDOTHER simulation the deposition decrease does not substantially change during the year (18\%, DJF: 19\%, JJA: 17\%).
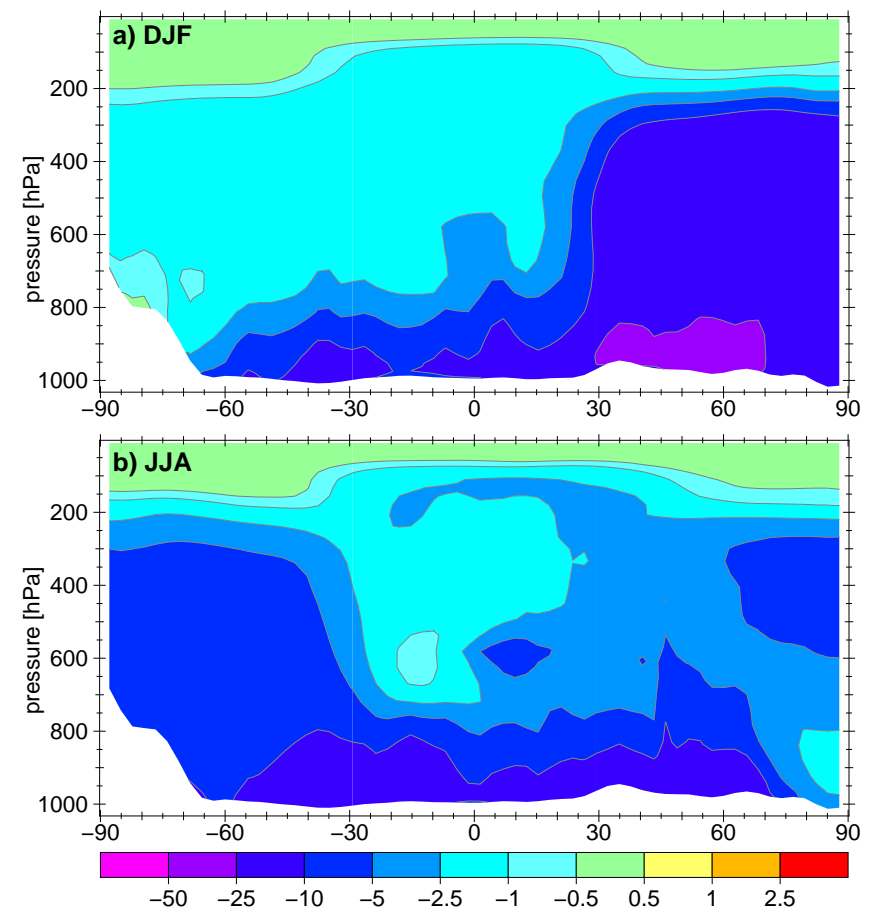

Fig. 7. Zonal mean relative difference ( $\frac{\text { REDOTHER-BASE }}{\text { BASE }} * 100 \%$ ) of the $\mathrm{NO}_{\mathrm{x}}$ mixing ratio in $\%$ averaged for (a) December, January, February and (b) June, July and August.
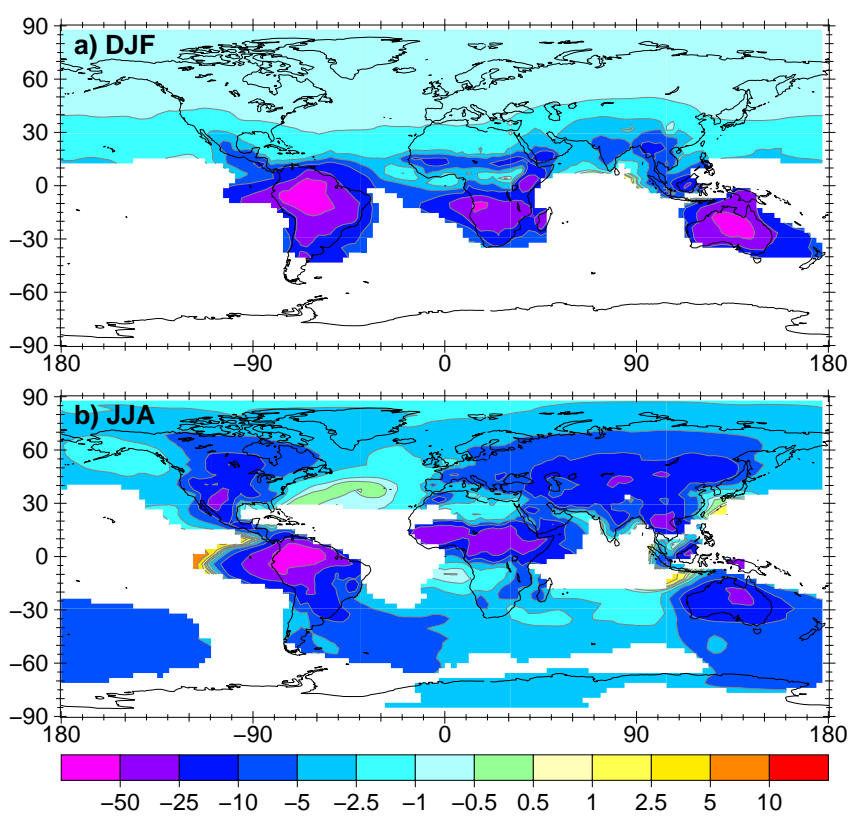

Fig. 8. Relative difference ( $\frac{\text { NOBIONO-BASE }}{\text { BASE }} * 100 \%$ ) of the lower tropospheric mixing ratio of PAN in \% (regions with values below $50 \mathrm{pmol} \mathrm{mol}^{-1}$ in the BASE run are excluded from the calculation) averaged for (a) December, January, February and (b) June, July and August. 

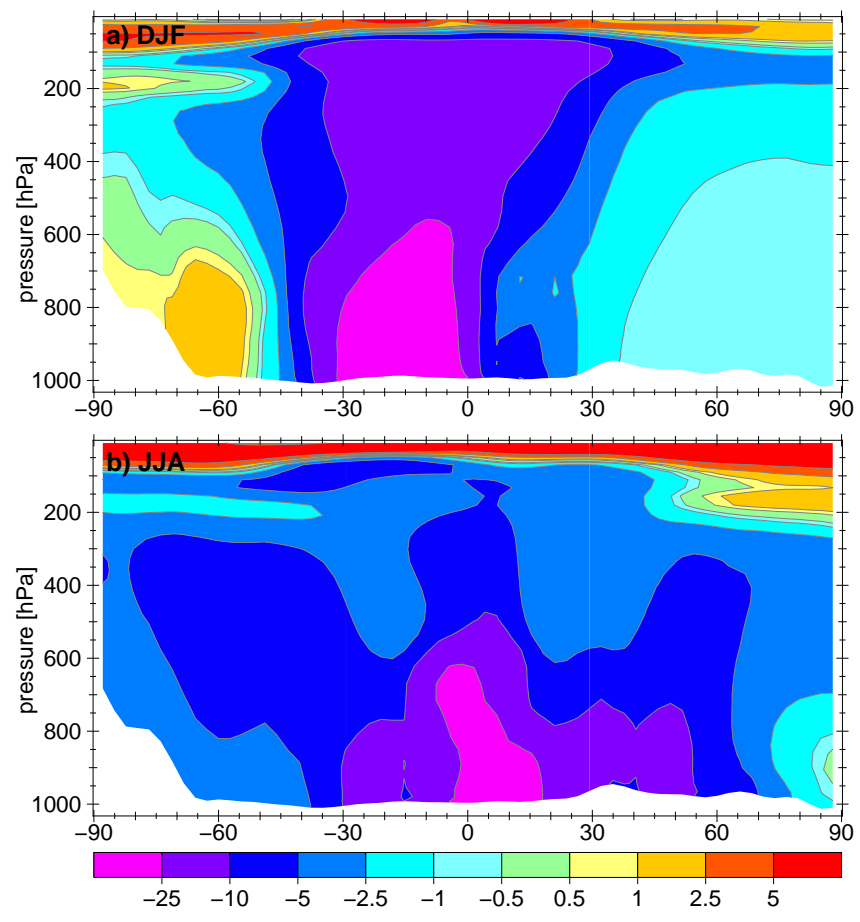

Fig. 9. Zonal mean relative difference ( $\frac{\text { NOBIONO-BASE }}{\text { BASE }} * 100 \%$ ) of the PAN mixing ratio in $\%$ averaged for (a) December, January, February and (b) June, July and August.
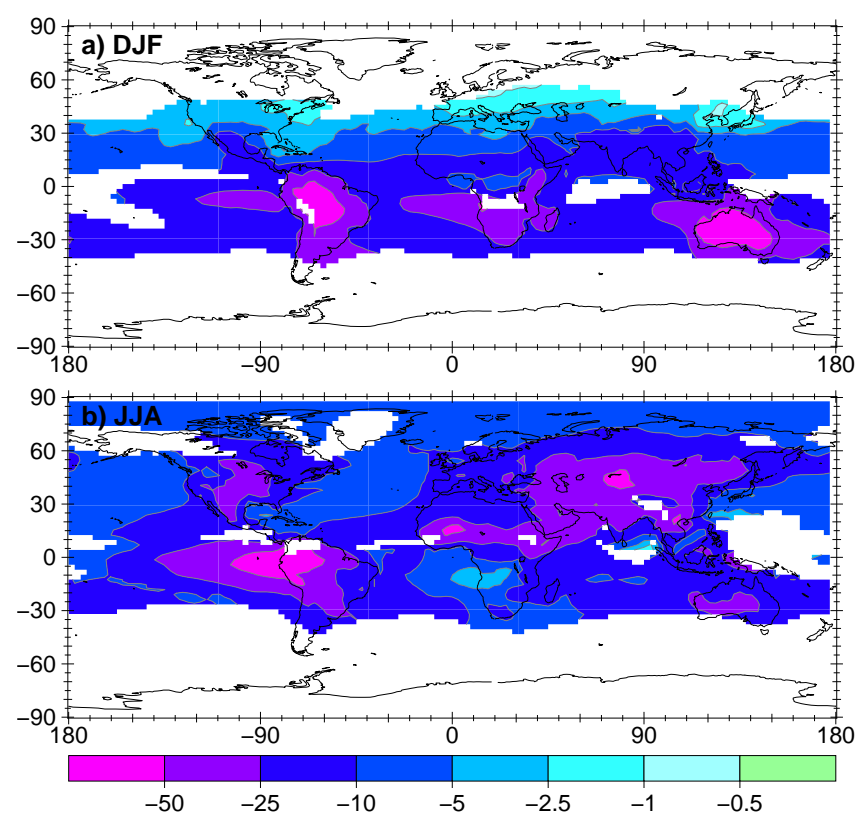

Fig. 10. Relative difference ( $\frac{\text { NOBIONO-BASE }}{\mathrm{BASE}} * 100 \%$ ) of the lower tropospheric mixing ratio of $\mathrm{HNO}_{3}$ in \% (region with values below $30 \mathrm{pmol} \mathrm{mol}^{-1}$ in the BASE simulation are excluded from the calculation) averaged for (a) December, January, February and (b) June, July and August.
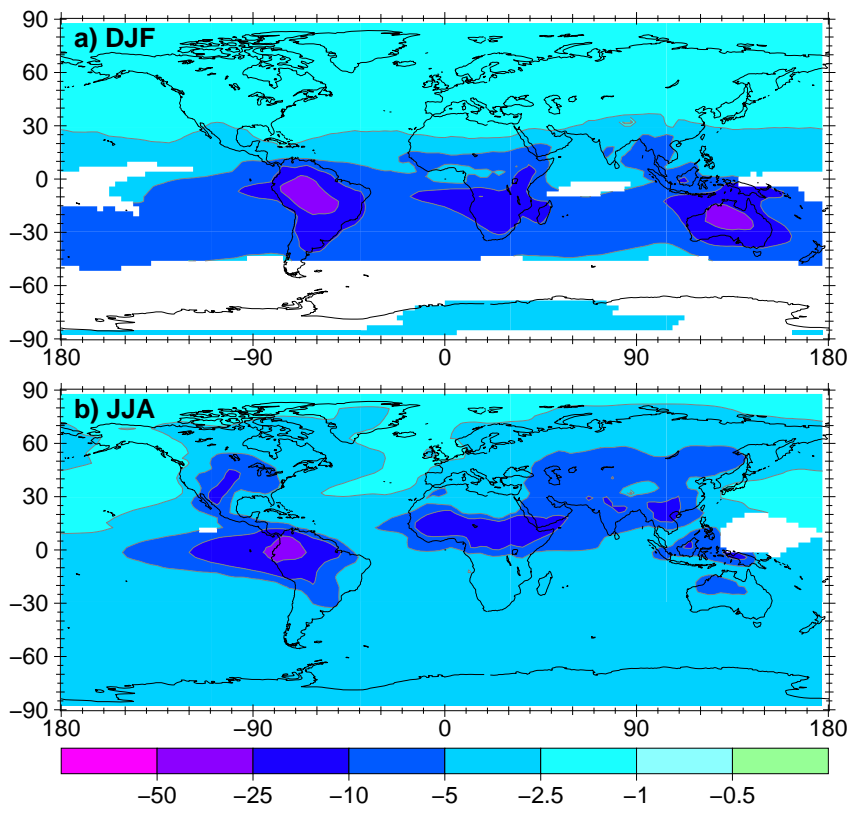

Fig. 11. Relative difference ( $\frac{\text { NOBIONO-BASE }}{\text { BASE }} * 100 \%$ ) of the lower tropospheric mixing ratio of $\mathrm{O}_{3}$ in $\%$ (regions with values below $25 \mathrm{nmol} \mathrm{mol}^{-1}$ in the BASE simulation are excluded from the calculation) averaged for (a) December, January, February and (b) June, July and August.

\subsection{4 $\mathrm{O}_{3}$}

The mixing ratio of $\mathrm{O}_{3}$ in the NOBIONO simulation compared to the BASE simulation decreases by $5 \%$ in the LT during both seasons, with the greatest decline above the continents (Fig. 11). The maximum relative decrease during DJF is $38 \%$ and during JJA it is $33 \%$. The maximum absolute decrease (16.2 $\mathrm{nmol} \mathrm{mol}^{-1}$ ) occurs during DJF above Australia (Fig. 11a). In contrast to what was found for $\mathrm{NO}_{\mathrm{x}}$, there is no region with increasing $\mathrm{O}_{3}$ mixing ratios. The removal of SNOx is less effective in reducing the $\mathrm{O}_{3}$ mixing ratio during JJA (17\%) than during DJF (7\%). This is because the formation of $\mathrm{O}_{3}$ through $\mathrm{SNOx}$ competes with other strong sources of $\mathrm{NO}_{\mathrm{x}}$ during JJA in the Northern Hemisphere, whereas SNOx is relatively much more important the formation of $\mathrm{O}_{3}$ during DJF in the Southern Hemisphere. Furthermore, as was noted above for the PAN formation in the Northern Hemisphere the simulated $\mathrm{O}_{3}$ production depends more on VOC and other $\mathrm{NO}_{\mathrm{x}}$ sources than SNOx, Beekmann and Vautard (2009) show for example different photochemical regimes in Europe.

In the zonal mean distribution (not shown) a similar pattern of the influence of convection can be seen as already discussed for $\mathrm{NO}_{\mathrm{x}}$ and PAN. But due to the longer lifetime of $\mathrm{O}_{3}$ the relative change is a maximum decrease of $13 \%$ (DJF) and $10 \%$ (JJA), which is not as strong and is more evenly distributed above all latitudes, as well as in the vertical direction. In the zonal mean there is, as with the horizontal, no region in which the mean $\mathrm{O}_{3}$ mixing ratio increases. 

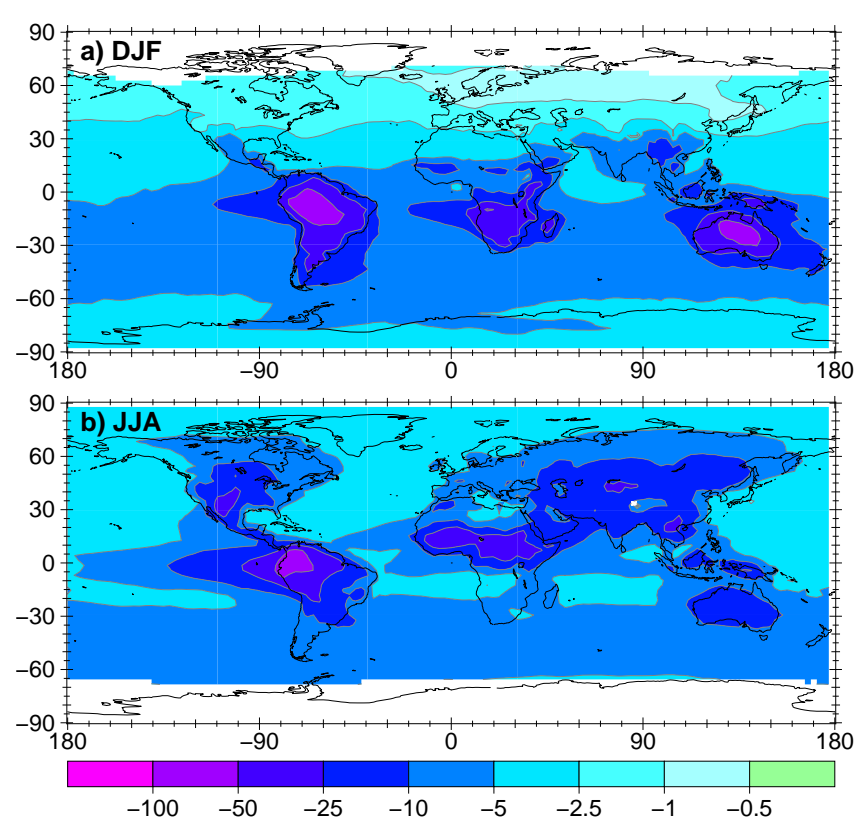

Fig. 12. Relative difference ( $\frac{\text { NOBIONO-BASE }}{\text { BASE }} * 100 \%$ ) of the lower tropospheric concentration of $\mathrm{OH}$ in \% (regions with values below $10^{4}$ molec $\mathrm{cm}^{-3}$ in the BASE simulation are excluded from the calculation) averaged for (a) December, January, February and (b) June, July and August.

Interestingly, in contrast to these results for SNOx, in the REDOTHER similation the mean $\mathrm{LT}_{3}$ mixing ratio only decreases by $2.7 \%$ (DJF) and $1.8 \%$ (JJA). In the zonal mean the increase does not exceed $5 \%$.

\subsubsection{OH}

When we exclude the contribution of SNOx, the mean LT OH concentration decreases by $10 \%$ during DJF and $9 \%$ during JJA. The largest relative decrease is $65 \%$ during DJF and $62 \%$ during JJA above the tropical land regions. During DJF the decrease is shifted to the southern tropics and to the northern tropics during JJA (Fig. 12). Note that during JJA an absolute increase above the Antarctic region is calculated, but the $\mathrm{OH}$ concentration here is less than $1 \times 10^{4}$ molec cm $^{-3}$.

The decrease is in part induced directly by $\mathrm{NO}_{\mathrm{x}}$ through Eq. (R3), and in part indirectly by the lower $\mathrm{O}_{3}$ mixing ratio, leading to less primary $\mathrm{OH}$ production, and therefore to a decrease of the $\mathrm{OH}$ concentration in the LT.

$\mathrm{NO}+\mathrm{HO}_{2} \rightarrow \mathrm{OH}+\mathrm{NO}_{2}$

The largest relative decrease in the zonal mean concentration of $\mathrm{OH}$ is $19 \%$ during DJF and $16 \%$ during JJA. This maximum of the relative decrease in the $\mathrm{OH}$ concentration without SNOx is nearly detached from the surface, despite the surface source of SNOx (Fig. 13). At the surface OH production is mainly related to the reaction of $\mathrm{O}\left({ }^{1} \mathrm{D}\right)$ with water,
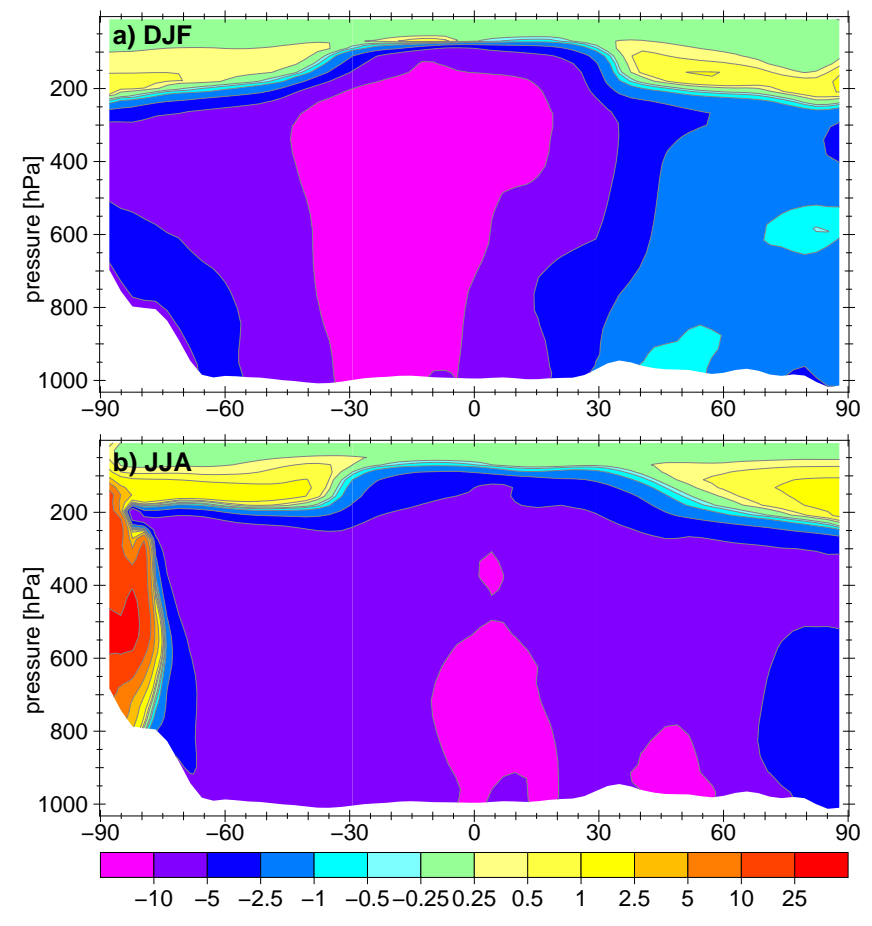

Fig. 13. Zonal mean relative difference ( $\frac{\text { NOBIONO-BASE }}{\text { BASE }} * 100 \%$ ) of the $\mathrm{OH}$ concentration in $\%$ averaged for (a) December, January, February and (b) June, July and August.
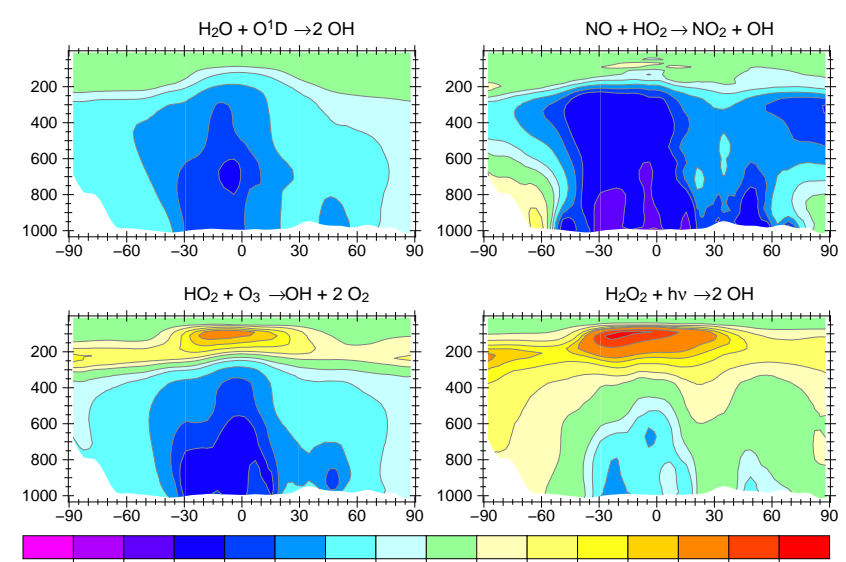

$\begin{array}{lllllllllllllll}-40 & -30 & -20 & -10 & -7.5 & -5 & -2.5 & -1 & 1 & 2.5 & 5 & 7.5 & 10 & 20 & 30\end{array}$

Fig. 14. Zonal mean relative change in the $\mathrm{OH}$ production of the four major $\mathrm{OH}$ producing reactions in the NOBIONO simulation compared to the BASE simulation over one year.

while at higher altitudes it depends more on the reaction of $\mathrm{NO}$ with $\mathrm{HO}_{2}$ (Eq. R3, see also Fig. 3). In the zonal mean the shift to the Southern Hemisphere during DJF is stronger than the shift during JJA to the Northern Hemisphere. The major driving reactions for the absolute decrease are the reaction of $\mathrm{H}_{2} \mathrm{O}$ with $\mathrm{O}\left({ }^{1} \mathrm{D}\right)$, reaction $\mathrm{R} 3$, and $\mathrm{HO}_{2}$ with $\mathrm{O}_{3}$ and photolysis of $\mathrm{H}_{2} \mathrm{O}_{2}$. The relative contribution of the four major $\mathrm{OH}$ producing reactions shows their strongest decrease in the 

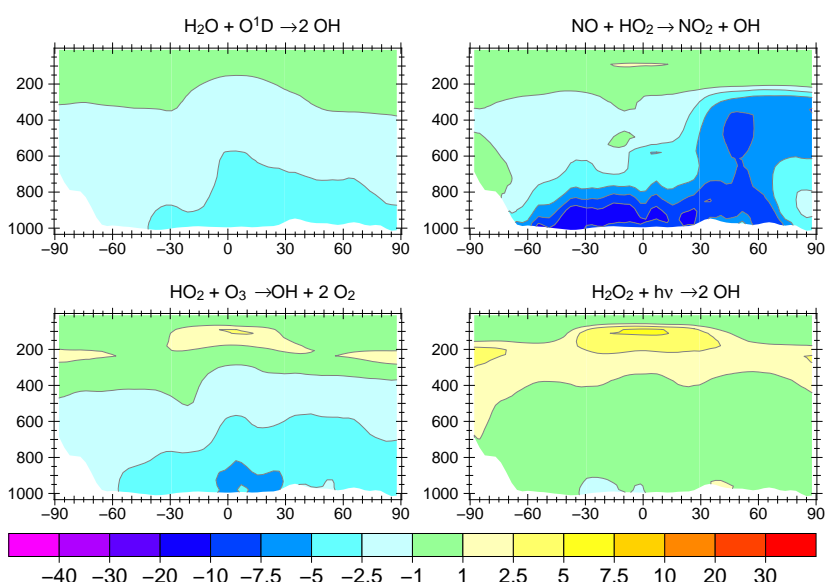

Fig. 15. Zonal mean relative change in the $\mathrm{OH}$ production of the four major $\mathrm{OH}$ producing reactions in the REDOTHER simulation compared to the BASE simulation over one year.

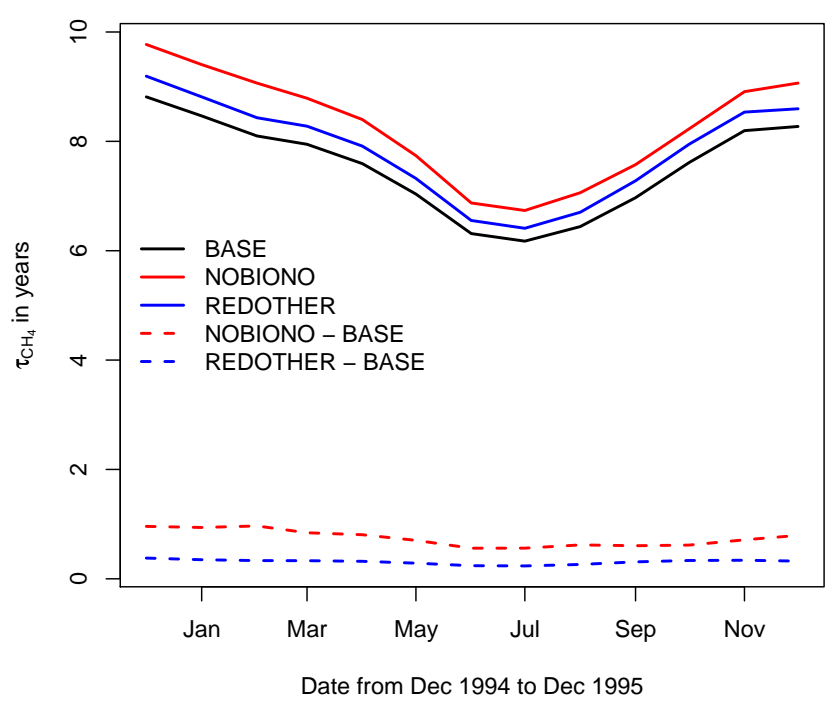

Fig. 16. Seasonal cycle of monthly mean lifetime of $\mathrm{CH}_{4}$ from December 1994 to December 1995 in years (calculated according to Lawrence et al., 2001).

lower latitudes throughout the year for the NOBIONO simulation (Fig. 14), whereas the the largest changes in the REDOTHER simulation are located much closer to the surface (Fig. 15) and are not as large as in the NOBIONO simulation.

In the REDOTHER simulation, with a $4 \%$ decrease during both seasons in the LT, the region with the strongest decrease is always located over the Northern Hemisphere and the maximum relative decreases are only $15 \%$ and $11 \%$, respectively.

\subsubsection{Summary for the trace gases}

By following the reaction chain from $\mathrm{NO}_{\mathrm{x}}$ through $\mathrm{O}_{3}$ and $\mathrm{OH}$, including the branches of $\mathrm{HNO}_{3}$ and PAN, the correlation of the change in the mixing ratio between the BASE

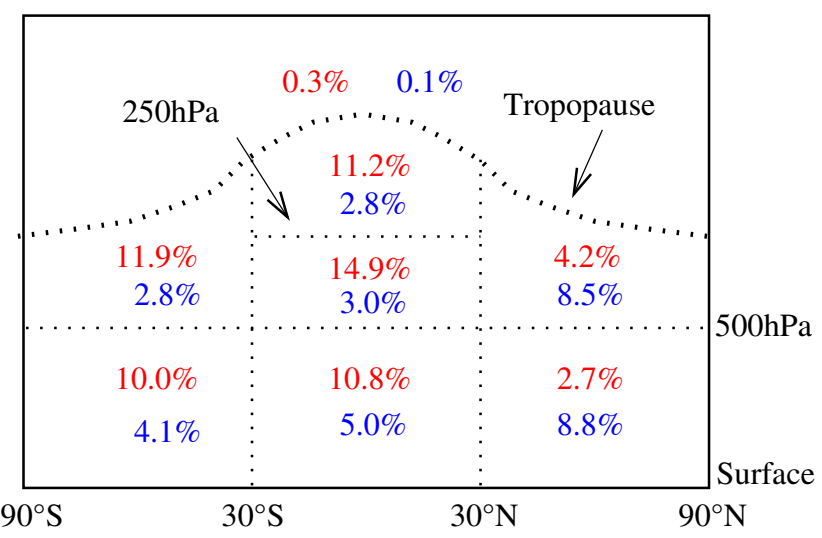

Fig. 17. Relative increase of $\tau_{\mathrm{CH}_{4}}\left(\frac{\tau_{\mathrm{CH}_{4}} \text {, simulation }-\tau_{\mathrm{CH}_{4}, \mathrm{BASE}}}{\tau_{\mathrm{CH}_{4}, \mathrm{BASE}}} * 100 \%\right)$ for the NOBIONO (red) and REDOTHER (blue) simulation in various zonal subdomains of the atmosphere (calculated according to Lawrence et al., 2001).

and NOBIONO simulation with the SNOx source declines. The strongest correlations can be found in the southern hemispheric mid-latitudes, which indicates an important role of SNOx in that region.

Although the total $\mathrm{NO}_{\mathrm{x}}$ emission decreases in the NOBIONO simulation, we simulate an increase in the LT $\mathrm{NO}_{\mathrm{x}}$ mixing ratio during DJF in the Northern Hemisphere. When reducing the other surface $\mathrm{NO}_{\mathrm{x}}$ emissions in the REDOTHER simulation, we did not see an increase in the mixing ratio. This is because the influence on the $\mathrm{O}_{3}$ and $\mathrm{OH}$ mixing ratios in the NOBIONO simulation is stronger than for the REDOTHER simulation and the feedback on $\tau_{\mathrm{NO}}$ is not strong enough in the REDOTHER simulation to increase the mixing ratio with reduced surface $\mathrm{NO}_{\mathrm{x}}$ emissions. Our results suggest that SNOx has a stronger influence on the related chemical processes than the remaining $\mathrm{NO}_{\mathrm{x}}$ sources due to the geographical distribution.

\subsection{Influence of SNOx on the oxidizing efficiency}

The oxidation of CO and VOC in the atmosphere is mainly driven by $\mathrm{OH}$. As a measure for the oxidizing efficiency of the atmosphere, $\tau_{\mathrm{CH}_{4}}$ is calculated for all simulations according to Lawrence et al. (2001). The trend of monthly mean values is depicted in Fig. 16. The mean $\tau_{\mathrm{CH}_{4}}$ averaged for one year (December 1994 to November 1995) for the BASE simulation is 7.25 years. It is 7.96 years in the NOBIONO simulation, a $9.8 \%$ increase without SNOx and 7.6 years (a $4 \%$ increase) for the REDOTHER simulation. The maximum prolongation of 0.97 years (12\%) occurs in Febuary 1995 for the NOBIONO simulation and 0.38 years $(4 \%)$ in December 1994 for the REDOTHER simulation.

The changes in $\tau_{\mathrm{CH}_{4}}$ are not equally distributed over the globe. In the Southern Hemisphere and low-latitudes the relative influence is noticeably greater than in the northern 
latitudes for the NOBIONO simulation (Fig. 17). This agrees with the smaller relative change in the $\mathrm{OH}$ concentration in the northern latitudes (Fig. 12). In the zonal mean, the relative changes are slightly larger above $500 \mathrm{hPa}$ for the NOBIONO simulation, despite the origin of SNOx at the surface. Beginning from the surface source of SNOx and following the reaction chain from $\mathrm{NO}_{\mathrm{x}}$ over $\mathrm{O}_{3}$ and $\mathrm{OH}$ in each step, the relative difference of our two simulations becomes smaller near the surface and larger at higher altitudes. This trend corroborates the larger relative change of the oxidizing efficiency at higher altitudes. However, only $\sim 15 \%$ of the absolute amount of $\mathrm{CH}_{4}$ in the troposphere is oxidized above $500 \mathrm{hPa}$ (Lawrence et al., 2001).

Labrador et al. (2004) modelled a decrease of $15 \%$ in $\tau_{\mathrm{CH}_{4}}$ in a simulation with $5 \mathrm{Tg}(\mathrm{N}) \mathrm{NO}_{\mathrm{x}}$ produced by lightning relative to one with no lightning $\mathrm{NO}_{\mathrm{x}}$. Compared to this, SNOx is somewhat less effective in altering the oxidizing efficiency of the atmosphere, which is interesting, given that $\mathrm{CH}_{4}$ oxidation is more effective near the surface where SNOx is emitted, due to the strong temperature dependence of the reaction of $\mathrm{OH}$ with $\mathrm{CH}_{4}$. The change in the oxidizing efficiency due to lightning $\mathrm{NO}_{\mathrm{x}}$ is larger than due to SNOx, even though the total emission rate is lower. This is because at higher altitudes the $\mathrm{NO}: \mathrm{NO}_{2}$ ratio is greater, so that with more $\mathrm{NO}$ the $\mathrm{NO}_{\mathrm{x}}$ lifetime is not diminished as strongly as near the surface. Furthermore at higher altitudes more NO results in higher $\mathrm{OH}$ yields by reaction with $\mathrm{HO}_{2}$.

\section{Conclusions and outlook}

The emission of NO from soils plays an important role for chemical reactions in the atmosphere in our simulations. Lower global mean $\mathrm{NO}_{\mathrm{x}}$ mixing ratios without $\mathrm{SNOx}$ lead to lower global $\mathrm{O}_{3}$ mixing ratios in the LT. The lower $\mathrm{O}_{3}$ mixing ratios result in lower $\mathrm{OH}$ concentrations. This results in an enhanced lifetime of $\mathrm{NO}_{\mathrm{x}}$ in regions with other dominating sources of $\mathrm{NO}_{\mathrm{x}}$. Hence the $\mathrm{NO}_{\mathrm{x}}$ mixing ratios increases in some regions, despite lower emissions when SNOx is neglected in our NOBIONO simulation. This effect did not occur in the REDOTHER simulation, in which we comparably reduced the remaining surface NO emissions. From this it follows that although $\mathrm{NO}_{\mathrm{x}}$ is a short-lived tracer it indirectly influences chemical processes in regions with low SNOx through feedback with $\mathrm{O}_{3}$ and $\mathrm{OH}$. By following the reaction chain up to PAN and $\mathrm{HNO}_{3}$, we detected a dominating role of SNOx compared to VOC in the mid-latitudes of the Southern Hemisphere. Also by following the reaction chain ( $\mathrm{SNOx} \rightarrow \mathrm{NO}_{\mathrm{x}} \rightarrow \mathrm{O}_{3} \rightarrow \mathrm{OH}$ ), the magnitude of relative effects are shifted step by step to higher altitudes in the troposphere.

Through reaction of $\mathrm{NO}$ with $\mathrm{HO}_{2}$, $\mathrm{SNOx}$ is directly involved in the production of $\mathrm{OH}$. SNOx also has, through $\mathrm{O}_{3}$, an indirect influence on $\mathrm{OH}$ production. With $\mathrm{OH}$ formed by SNOx through these pathways, $\tau_{\mathrm{CH}_{4}}$ is decreased consider- ably, and the influence of SNOx on the tropospheric oxidizing efficiency is considerable, approximately $10 \%$. Reducing the other surface $\mathrm{NO}$ emissions by the same amount only lead to an increase of $4 \%$ in $\tau_{\mathrm{CH}_{4}}$.

The notable modelled influence of SNOx on directly and indirectly related trace gases shown in this work supports further efforts to improve the parameterization of SNOx in CTMs, as also proposed by Jaeglé et al. (2005).

Acknowledgements. We thank the anonymous referees for their constructive and fruitful comments. We appreciate the help of the modellers and the MESSy team, especially T. Butler, A. Kerkweg, P. Jöckel and M. Tanarhte. We acknowlegde the International Max Planck Research School on Atmospheric Chemistry and Physics for financial support.

The service charges for this open access publication have been covered by the Max Planck Society.

Edited by: R. Vautard

\section{References}

Beekmann, M. and Vautard, R.: A modelling study of photochemical regimes over Europe: robustness and variability, Atmos. Chem. Phys. Discuss., 9, 1521-1560, 2009,

http://www.atmos-chem-phys-discuss.net/9/1521/2009/.

Bertram, T. H., Heckel, A., Richter, A., Burrows, J. P., and Cohen, R. C.: Satellite measurements of daily variations in soil $\mathrm{NO}_{\mathrm{x}}$ emissions, Geophys. Res. Lett., 32, L24812, doi:10.1029/ 2005GL024640, 2005.

Bouwman, A. F. and Boumans, L. J. M.: Emissions of $\mathrm{N}_{2} \mathrm{O}$ and NO from fertilized fields: Summary of available measurement data, Global Biogeochem. Cy., 16, 1058, doi:10.1029/ 2001GB001811, 2002.

Brasseur, G. P., Orlando, J. J., and Tyndall, G. S., (Eds.): Atmospheric chemistry and global change, Oxford University Press, New York, 1999.

Cleary, P. A., Wooldridge, P. J., Millet, D. B., McKay, M., Goldstein, A. H., and Cohen, R. C.: Observations of total peroxy nitrates and aldehydes: measurement interpretation and inference of $\mathrm{OH}$ radical concentrations, Atmos. Chem. Phys., 7, 19471960, 2007, http://www.atmos-chem-phys.net/7/1947/2007/.

Davidson, E. A. and Kingerlee, W.: A global inventory of nitric oxide emissions from soils, Nutr. Cycl. Agroecosys., 48, 37-50, 1997.

Delon, C., Reeves, C. E., Stewart, D. J., Serça, D., Dupont, R., Mari, C., Chaboureau, J.-P., and Tulet, P.: Biogenic nitrogen oxide emissions from soils - impact on $\mathrm{NO}_{\mathrm{x}}$ and ozone over West Africa during AMMA (African Monsoon Multidisciplinary Experiment): modelling study, Atmos. Chem. Phys., 8, 2351-2363, 2008, http://www.atmos-chem-phys.net/8/2351/2008/.

Denman, K. L., Brasseur, G., Chidthaisong, A., Ciais, P., Cox, P. M., Dickinson, R. E., Hauglustaine, D., Heinze, C., Holland, E., Jacob, D., Lohmann, U., Ramachandran, S., da Silva Dias, P. L., Wofsy, S. C., and Zhang, X.: Couplings Between Changes in the Climate System and Biogeochemistry, in: Climate Change 2007: The Physical Science Basis, Contribution of Working 
Group I to the Fourth Assessment Report of the Intergovernmental Panel on Climate Change, Cambridge University Press, Cambridge, United Kingdom and New York, NY, USA, 499587, 2007.

Firestone, M. K. and Davidson, E. A.: Mikrobiological basis of NO and $\mathrm{N}_{2} \mathrm{O}$ production and consumption in soil, in: Exchange of trace gases between terrestrial ecosystems and the atmosphere, edited by: Andreae, M. O. and Schimel, D. S., 7-21, 1989.

Fuglestvedt, J. S., Berntsen, T. K., Isaksen, I. S. A., Mao, H., Liang, X.-Z., and Wang, W.-C.: Climatic forcing of nitrogen oxides through changes in tropospheric ozone and methane; global 3D model studies, Atmos. Environ., 33, 961-977, 1999.

Ganzeveld, L. N., Lelieveld, J., Dentener, F. J., Krol, M. C., Bouwman, A. F., and Roelofs, G.-J.: Global soil-biogenic $\mathrm{NO}_{\mathrm{x}}$ emissions and the role of canopy processes, J. Geophys. Res., 107, 4321, doi:10.1029/2001JD001289, 2002a.

Ganzeveld, L. N., Lelieveld, J., Dentener, F. J., Krol, M. C., and Roelofs, G.-J.: Atmosphere-biosphere trace gas exchanges simulated with a single-column model, J. Geophys. Res., 107, 4320, doi:10.1029/2001JD000684, 2002b.

Ganzeveld, L. N., van Aardenne, J. A., Butler, T. M., Lawrence, M. G., Metzger, S. M., Stier, P., Zimmermann, P., and Lelieveld, J.: Technical Note: Anthropogenic and natural offline emissions and the online EMissions and dry DEPosition submodel EMDEP of the Modular Earth Submodel system (MESSy), Atmos. Chem. Phys. Discuss., 6, 5457-5483, 2006,

http://www.atmos-chem-phys-discuss.net/6/5457/2006/.

Isaksen, I. S. A. and Hov, Ø.: Calculation of trends in the tropospheric concentration of $\mathrm{O}_{3}, \mathrm{OH}, \mathrm{CO}, \mathrm{CH}_{4}$ and $\mathrm{NO}_{\mathrm{x}}$, Tellus, 39B, 271-285, 1987.

Jaeglé, L., Steinberger, L., Martin, R. V., and Chance, K.: Global partitioning of $\mathrm{NO}_{\mathrm{x}}$ sources using satellite observations: relative roles of fossil fuel combustion, biomass burning and soil emissions, Faraday Discuss., 130, 407-423, 2005.

Jöckel, P., Sander, R., Kerkweg, A., Tost, H., and Lelieveld, J.: Technical Note: The Modular Earth Submodel System (MESSy) - a new approach towards Earth System Modeling, Atmos. Chem. Phys., 5, 433-444, 2005,

http://www.atmos-chem-phys.net/5/433/2005/.

Jöckel, P., Tost, H., Pozzer, A., Brühl, C., Buchholz, J., Ganzeveld, L., Hoor, P., Kerkweg, A., Lawrence, M. G., Sander, R., Steil, B., Stiller, G., Tanarhte, M., Taraborrelli, D., van Aardenne, J., and Lelieveld, J.: The atmospheric chemistry general circulation model ECHAM5/MESSy1: consistent simulation of ozone from the surface to the mesosphere, Atmos. Chem. Phys., 6, 50675104, 2006, http://www.atmos-chem-phys.net/6/5067/2006/.

Kerkweg, A., Buchholz, J., Ganzeveld, L., Pozzer, A., Tost, H., and Jöckel, P.: Technical Note: An implementation of the dry removal processes DRY DEPosition and SEDImentation in the Modular Earth Submodel System (MESSy), Atmos. Chem. Phys., 6, 4617-4632, 2006a.

Kerkweg, A., Sander, R., Tost, H., and Jöckel, P.: Technical note: Implementation of prescribed (OFFLEM), calculated (ONLEM), and pseudo-emissions (TNUDGE) of chemical species in the Modular Earth Submodel System (MESSy), Atmos. Chem. Phys., 6, 3603-3609, 2006b.

Labrador, L. J., von Kuhlmann, R., and Lawrence, M. G.: The effects of lightning-produced $\mathrm{NO}_{\mathrm{x}}$ and its vertical distribution on atmospheric chemistry: sensitivity simulations with MATCH-
MPIC, Atmos. Chem. Phys., 5, 1815-1834, 2005, http://www.atmos-chem-phys.net/5/1815/2005/.

Labrador, L. J., von Kuhlmann, R., and Lawrence, M. G.: Strong sensitivity of the global mean $\mathrm{OH}$ concentration and the tropospheric oxidizing efficency to the source of $\mathrm{NO}_{\mathrm{x}}$ from lightning, Geophys. Res. Lett., 31, L06102, doi:10.1029/2003GL019229, 2004.

Lawrence, M. G., Jöckel, P., and von Kuhlmann, R.: What does the global mean $\mathrm{OH}$ concentration tell us?, Atmos. Chem. Phys., 1, 37-49, 2001, http://www.atmos-chem-phys.net/1/37/2001/.

Olivier, J. G. J., Bouwman, A. F., Vandermaas, C. W. M., and Berdowski, J. J. M.: Emission database for global atmospheric research (EDGAR), Environ. Monit. Assess., 31, 93-106, 1994.

Olson, J.: World ecosystems (WE1.4): Digital raster data on a 10 min geographic 1080x2160 grid square, Global Ecosystem Database, Version 1.0: DISC A, edited by: NOAA National Geophysical Data Center, 1992.

Roberts, J. M., Stroud, C. A., Jobson, B. T., Trainer, M., Hereid, D., Williams, E., Fehsenfeld, F., Brune, W., Martinez, M., and Harder, H.: Application of a sequential reaction model to PANs and aldehyde measurements in two urban areas, Geophys. Res. Lett., 28, 4583-4586, 2001.

Sander, R., Kerkweg, A., Jöckel, P., and Lelieveld, J.: Technical note: The new comprehensive atmospheric chemistry module MECCA, Atmos. Chem. Phys., 5, 445-450, 2005, http://www.atmos-chem-phys.net/5/445/2005/.

Simpson, D.: Biogenic emissions in Europe: 2. Implications for ozone control strategies, J. Geophys. Res., 100, 22891-22906, 1995.

Sitch, S., Cox, P. M., Collins, W. J., and Huntingford, C.: Indirect radiative forcing of climate change through ozone effects on the land-carbon sink, Nature, 448, 791-794, doi:10.1038/ nature06059, 2007.

Stehfest, E. and Bouwman, L.: $\mathrm{N}_{2} \mathrm{O}$ and $\mathrm{NO}$ emission from agricultural fields and soils under natural vegetation: summarizing available measurement data and modeling of global annual emissions, Nutr. Cycl. Agroecosys., 24, 207-228, 2006.

Steinkamp, J.: Globale Stickstoffmonoxid-Emissionen aus dem Boden: Literaturauswertung und Evaluierung des Modells ECHAM5/MESSy, Diploma thesis, Johannes-Gutenberg University, Mainz/Germany, 2007.

Stockwell, D. Z., Giannakopoulos, C., Plantevin, P.-H., Carver, G. D., Chipperfield, M. P., Law, K. S., Pyle, J. A., Shallcross, D. E., and Wang, K.-Y.: Modelling $\mathrm{NO}_{\mathrm{x}}$ from lightning and its impact on global chemical fields, Atmos. Environ., 33, 44774493, 1999.

Taraborrelli, D., Lawrence, M. G., Butler, T. M., Sander, R., and Lelieveld, J.: Mainz Isoprene Mechanism 2 (MIM2): an isoprene oxidation mechanism for regional and global atmospheric modelling, Atmos. Chem. Phys. Discuss., 8, 14033-14085, 2008, http://www.atmos-chem-phys-discuss.net/8/14033/2008/.

Taylor, K., Williamson, D., and Zwiers, F.: The sea surface temperature and sea ice concentration boundary conditions for AMIP II simulations; PCMDI Report, Tech. Rep. 60, Program for Climate Model Diagnosis and Intercomparison, 2000.

Tost, H.: Global Modelling of Cloud, Convection and Precipitation Influences on Trace Gases and Aerosols, Ph.D. thesis, Rheinische Friedrich-Wilhelms-University, Bonn/Germany, 2006. 
Tost, H., Jöckel, P., Kerkweg, A., Sander, R., and Lelieveld, J.: Technical note: A new comprehensive SCAVenging submodel for global atmospheric chemistry modelling, Atmos. Chem. Phys., 6, 565-574, 2006a.

Tost, H., Jöckel, P., and Lelieveld, J.: Influence of different convection parameterisations in a GCM, Atmos. Chem. Phys., 6, 54755493, 2006b.
Tost, H., Jöckel, P., and Lelieveld, J.: Lightning and convection parameterisations - uncertainties in global modelling, Atmos. Chem. Phys., 7, 4553-4568, 2007, http://www.atmos-chem-phys.net/7/4553/2007/.

Yienger, J. J. and Levy II, H.: Empirical model of global soilbiogenic $\mathrm{NO}_{\mathrm{x}}$ emissions, J. Geophys. Res., 100, 11447-11464, 1995. 